\title{
Unusual mineralization with niobian titanite and Bi-tellurides in scheelite skarn from Kamenné doly quarry near Písek, Moldanubian Zone, Bohemian Massif
}

\author{
Stanislav HOUZAR ${ }^{* *}$, Jiří LITOCHLEB² ${ }^{2}$ Jiří SEJKORA², Jan CEMPÍREK' ${ }^{1}$ Jaroslav CíCHA ${ }^{3}$ \\ ${ }^{1}$ Department of Mineralogy and Petrography, Moravian Museum, Zelnýtrh 6, 65937 Brno, Czech Republic; shouzar@mzm.cz \\ ${ }^{2}$ Department of Mineralogy and Petrology, National Museum, Václavské náméstí 78, 11579 Prague 1, Czech Republic \\ ${ }^{3}$ Prácheň Museum, Velké náměstí 114, 39724 Písek, Czech Republic \\ ${ }^{*}$ Corresponding author
}

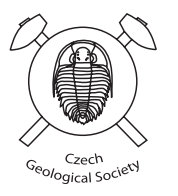

Clinopyroxene-garnet scheelite skarn containing accessory niobian titanite, native bismuth and Bi-tellurides of the $\mathrm{Bi}_{2} \mathrm{X}$ and $\mathrm{Bi}_{5} \mathrm{X}_{3}$ series, together with $\mathrm{Fe}$ - and $\mathrm{Fe}$-As sulphides, is associated with the contact of chondrodite marble with melanocratic granite-quartz syenite (durbachite). Hedenbergite-rich vein in this marble can be considered as an additional type of skarn. The presence of accessory niobian titanite is typical, in particular, of the veins. In addition to increased $\mathrm{Nb}$ contents $\left(\leq 10.6\right.$ wt. $\% \mathrm{Nb}_{2} \mathrm{O}_{5} ; \leq 0.164$ apfu $\left.\mathrm{Nb}\right)$ and locally $\mathrm{Ta}\left(\leq 4.07 \mathrm{Ta}_{2} \mathrm{O}_{5} ; \leq 0.038\right.$ apfu Ta), it is relatively rich in $\mathrm{Al}(\leq 0.253 \mathrm{apfu})$. Locally it contains elevated $\mathrm{Fe}, \mathrm{Sn}, \mathrm{Zr}$ and $\mathrm{F}$ contents. Negative correlations of $\mathrm{Al}+\mathrm{F}$ with $\mathrm{R}^{4+}$ and $\mathrm{Al}+\left(\mathrm{Nb}^{5+}, \mathrm{Ta}^{5+}\right)$ with $\mathrm{R}^{4+}$ accompanied by low contents of $\mathrm{Na}$ in titanite correspond to the substitutions $\mathrm{Al}(\mathrm{OH}, \mathrm{F})(\mathrm{TiO})_{-1}$ and $\mathrm{Al}(\mathrm{Nb}, \mathrm{Ta}) \mathrm{Ti}_{-2}$. Niobian titanite has anomalous composition if compared to skarn mineral assemblages worldwide. The Bi-(sulpho-) telluride with empiric formula $\mathrm{Bi}_{1.98}\left(\mathrm{Te}_{0.66} \mathrm{~S}_{0.34} \mathrm{Se}_{0.02}\right)_{\Sigma 1.02}$ is a member of the $\mathrm{Bi}_{2} \mathrm{X}$ series, whose members were described from numerous localities as unnamed minerals. In contrast to the published data this phase contains increased sulphur contents up to $0.33 \mathrm{apfu}$. The second Bi-(sulpho-) telluride with empiric formula $\left(\mathrm{Bi}_{4.51} \mathrm{Fe}_{0.40} \mathrm{Cd}_{0.03} \mathrm{~Pb}_{0.02} \mathrm{Sb}_{0.01} \mathrm{As}_{0.01}\right)_{\Sigma 4.98}\left(\mathrm{Te}_{1.58} \mathrm{~S}_{1.36} \mathrm{Se}_{0.08}\right)_{\Sigma 3.02}$ is probably a S-rich member of the $\mathrm{Bi}_{5} \mathrm{X}_{3}$ series. In the evolution of the skarn it is possible to distinguish stage I responsible for the formation of the older $\mathrm{Mg}$ - and younger Ca-skarns, and stage II, characterised by increased Fe contents. The scheelite-sulphide mineralization was formed during a third (retrogression) stage followed by brittle deformation. Emplacement of siderite \pm quartz veins represents the fourth (terminal) stage of mineralization.

Keywords: niobian titanite, Bi tellurides, scheelite, sulphides, electron microprobe, marble, skarn, Moldanubian Zone Received: 30 January 2008; accepted 5 March 2008; handling editor: S. Vrána

\section{Introduction}

Titanite $\mathrm{CaTiOSiO}_{4}$, including varieties rich in $(\mathrm{Al}, \mathrm{OH}$, F) components, is a typical and common mineral in calc-silicate rocks of various genetic types. In contrast, $\mathrm{Nb}$-rich titanite $\left(>0.5 \mathrm{wt} \% \mathrm{Nb}_{2} \mathrm{O}_{5}\right.$ ) is rather rare, being restricted mainly to peralkaline rocks and pegmatites. Its occurrence in calc-silicate rocks - including skarns - is exceptional. The Bi-tellurides on the other hand can be typical accessory minerals in skarns but so far they were considered very scarce in skarns of the Bohemian Massif.

Within the Bohemian Massif, skarns of variable genetic types and various mineral assemblages represent characteristic rock type especially in the Moldanubian Zone. Besides the regionally metamorphosed skarns (e. g. Němec 1991; Pertold et al. 1997), there are also smaller bodies of contact skarns restricted to contacts of marbles with silicate rocks (Suk 1974; Fišera et al. 1986; Houzar 1998; Drahota et al. 2005). Unusual mineralizations with niobian titanite and Bi-tellurides were recently discovered in a skarn developed at the contact between chondrodite marble and potassic melanocratic granite to quartz syenite (durbachite) at the Kamenné doly quarry near Písek. This unusual assemblage is in focus of the current contribution.

\section{Geological setting}

The Písek area belongs to the Moldanubian Zone, the presumed high-grade root of the Variscan orogen in Bohemian Massif (Dallmeyer et al. 1995). It features leucocratic migmatites and orthogneisses, together with minor granulite occurrences accompanied by ultramafic rocks, representing the Podolsko Complex. In addition there are minor domains of graphite quartzite and marble enclosed in biotite gneiss belonging most likely to the Varied Unit (Fig. 1). The metamorphic complex was intruded by granitoid plutons, including amphibole-biotite granodiorite (Červená type), by ultrapotassic porphyritic amphibolebiotite melagranite to quartz syenite (durbachite), and 


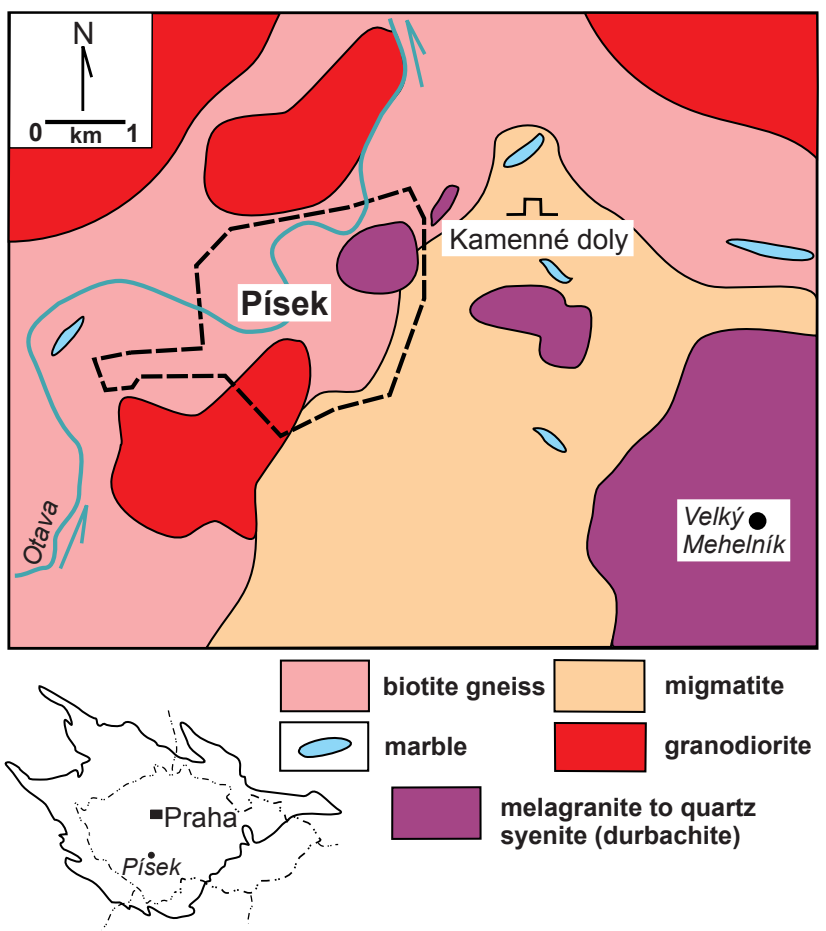

Fig. 1 Geological sketch of the Písek area (modified from the Czech Geological Survey map 1:50 000).

small dykes of tourmaline granite, aplite and pegmatite (Fišera et al. 1978). Marbles in the Písek area occur as numerous small intercalations in migmatites and biotite gneiss, often cross-cut by pegmatite dykes. The marbles are dominantly calcic but the mineral assemblage $\mathrm{Phl}+$ $\mathrm{Chl}+\mathrm{Spl}+\mathrm{Chn} \pm \mathrm{Fo} \pm \mathrm{Chu} \pm \mathrm{Tr} \pm \mathrm{Di}$ indicates a former presence of a dolomite admixture. Contact skarns associated with marbles commonly contain wollastonite, diopside and grossular, or rare vesuvianite, scheelite and exceptional axinite (Kratochvíl 1962; Fišera et al. 1986).

The quarry Kamenné doly, located at the NE outskirts of the town of Písek, next to the main road from Písek to Tábor, exposes mainly leucocratic migmatite and numerous intrusive bodies of durbachite, tens of metres in size. Both rock types enclose layers and xenoliths of marbles and calc-silicate rocks. Calcic marbles are often coarse-grained, with white or pale blue calcite, minor phlogopite and diopside. Another type of calcic marble is greyish white, with abundant $\mathrm{Mg}$-silicates, mainly phlogopite and chondrodite. Diopside and diopside-wollastonite reaction zones occur at the contact of marbles with migmatite. Smaller enclaves $(<20 \mathrm{~cm})$ of marble in nebulitic migmatites or granitoids are locally replaced by wollastonite + diopside assemblage. Small layers of calc-silicate gneiss, dominated by pyroxene with a lesser percentage of garnet, vesuvianite and scheelite also do occur. For example Morávek (1992) reported a
$2 \mathrm{~m}$ thick layer of calc-silicate gneiss with pyrite, quartz and scheelite impregnation, containing 0.9 wt. \% W and $0.10-0.76 \mathrm{~g} / \mathrm{t} \mathrm{Au}$. Dyke rocks are represented by leucogranites, simple tourmaline pegmatites with exceptional transition to complex, elbaite-bearing pegmatite of the LCT type. Quartz veins contain tourmaline and arsenopyrite (Cícha 2003).

\section{Analytical methods}

Chemical composition of minerals was studied by electron microprobe Cameca SX-100 (Laboratory of Electron Microscopy and Microanalysis, the joint facility of the Masaryk University and Czech Geological Survey in Brno; operator R. Škoda). The accelerating voltage was $15 \mathrm{kV}$, beam diameter 5-10 $\mu \mathrm{m}$, beam current $10-20$ $\mathrm{nA}$ and counting times $20 \mathrm{~s}$. Following standards and $\mathrm{K} \alpha$ lines were used: for niobian titanite: titanite $(\mathrm{Si}, \mathrm{Ca}$, $\mathrm{Ti})$, zircon $(\mathrm{Zr})$, metallic $\mathrm{Sn}(\mathrm{Sn})$, sanidine (Al), YGI $(\mathrm{Y}), \mathrm{ScP}_{5} \mathrm{O}_{14}(\mathrm{Sc})$, andradite $(\mathrm{Fe})$, rhodonite $(\mathrm{Mn})$, olivine $(\mathrm{Mg})$, columbite from Ivigtut $(\mathrm{Nb}), \mathrm{CrTa}_{2} \mathrm{O}_{6}(\mathrm{Ta})$, chromite $(\mathrm{Cr})$, metallic $\mathrm{V}(\mathrm{V})$, albite $(\mathrm{Na})$ and topaz $(\mathrm{F})$; standards for other silicates: sanidine $(\mathrm{K}, \mathrm{Si}, \mathrm{Al})$, benitoite $(\mathrm{Ba})$, hornblende $(\mathrm{Ti}), \mathrm{Rb}$-leucite $(\mathrm{Rb})$, gahnite $(\mathrm{Zn})$, metallic $\mathrm{Ni}(\mathrm{Ni})$, fluorapatite $(\mathrm{P})$ and vanadinite $(\mathrm{Cl})$.

Quantitative chemical analyses of sulphides and tellurides were obtained with the same analyser at accelerating voltage $25 \mathrm{kV}$, beam current $20 \mathrm{nA}$ and beam diameter $0.7-1 \mu \mathrm{m}$. The following standards were used: $\mathrm{Ag}(\mathrm{AgL} \alpha), \mathrm{PbS}(\mathrm{PbM} \alpha), \mathrm{CuFeS}_{2}(\mathrm{CuK} \alpha), \mathrm{FeS}_{2}(\mathrm{FeK} \alpha$, $\mathrm{SK} \alpha), \mathrm{CdTe}(\mathrm{CdL} \beta), \mathrm{Sb}_{2} \mathrm{~S}_{3}(\mathrm{SbL} \beta), \mathrm{Bi}(\mathrm{BiL} \alpha), \mathrm{Bi}_{2} \mathrm{Te}_{3}$ (TeL $\beta), \mathrm{Au}(\mathrm{Au} \mathrm{M} \alpha), \mathrm{HgTe}(\mathrm{HgM} \alpha)$, pararammelsbergite $(\mathrm{NiK} \alpha, \operatorname{AsL} \beta), \mathrm{Mn}(\mathrm{MnK} \alpha)$, Co $(\mathrm{CoK} \alpha), \operatorname{InAs}(\operatorname{InL} \alpha)$, $\mathrm{PbSe}(\mathrm{SeL} \beta), \mathrm{ZnS}(\mathrm{ZnK} \alpha)$

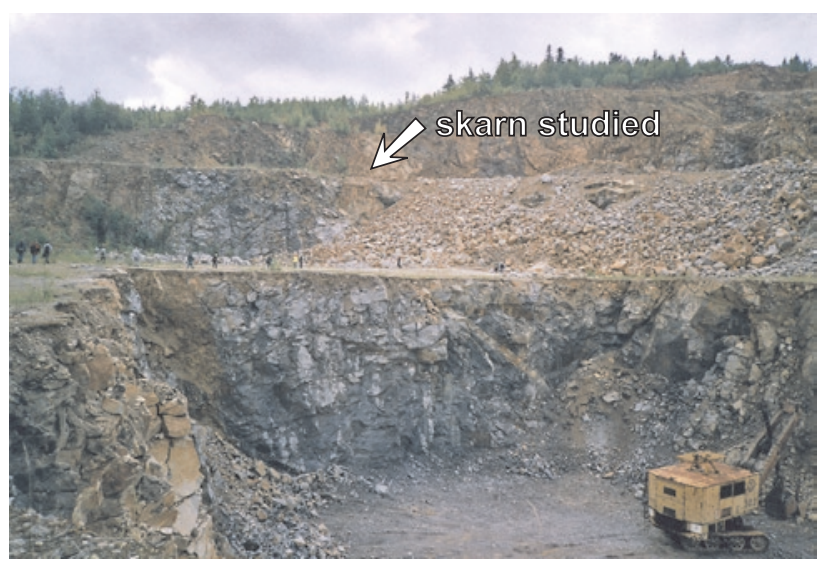

Fig. 2 Kamenné Doly quarry, position of the studied skarn is marked by arrow (photo J. Litochleb, 2005). 
Raw data were converted to concentrations using the PAP correction (Pouchou and Pichoir 1985). Ratio $\mathrm{MTi} / \mathrm{Si}(\mathrm{MTi}=\mathrm{Mg}+\mathrm{Fe}+\mathrm{Mn}+\mathrm{Ti}+\mathrm{Ca})$, was used for identification of chondrodite (after Gaspar 1992). Value of $\mathrm{X}_{\mathrm{F}}$ is defined as a $100 \mathrm{~F} /(\mathrm{F}+\mathrm{OH})$ ratio.

\section{Description of the marble and skarn}

The studied skarn body was exposed in the quarry owned by the company Kámen a písek, Ltd., Český Krumlov. It was found in the upper part of the quarry face at the $2^{\text {nd }}$ level in 1999 (Fig. 2); the last part of the skarn vanished in 2007. The skarn formed a zoned, irregular body several metres across, with relics of chondrodite marble in the central part. It was located at the contact of fine-grained nebulitic migmatite with porphyritic amphibole-biotite durbachite, both penetrated by a dyke of biotite leucogranite with nodular tourmaline (Fig. 3). Five paragenetic units (zones) were distinguished in the skarn. Mineral assemblages of marble and skarn are listed in Table 1.

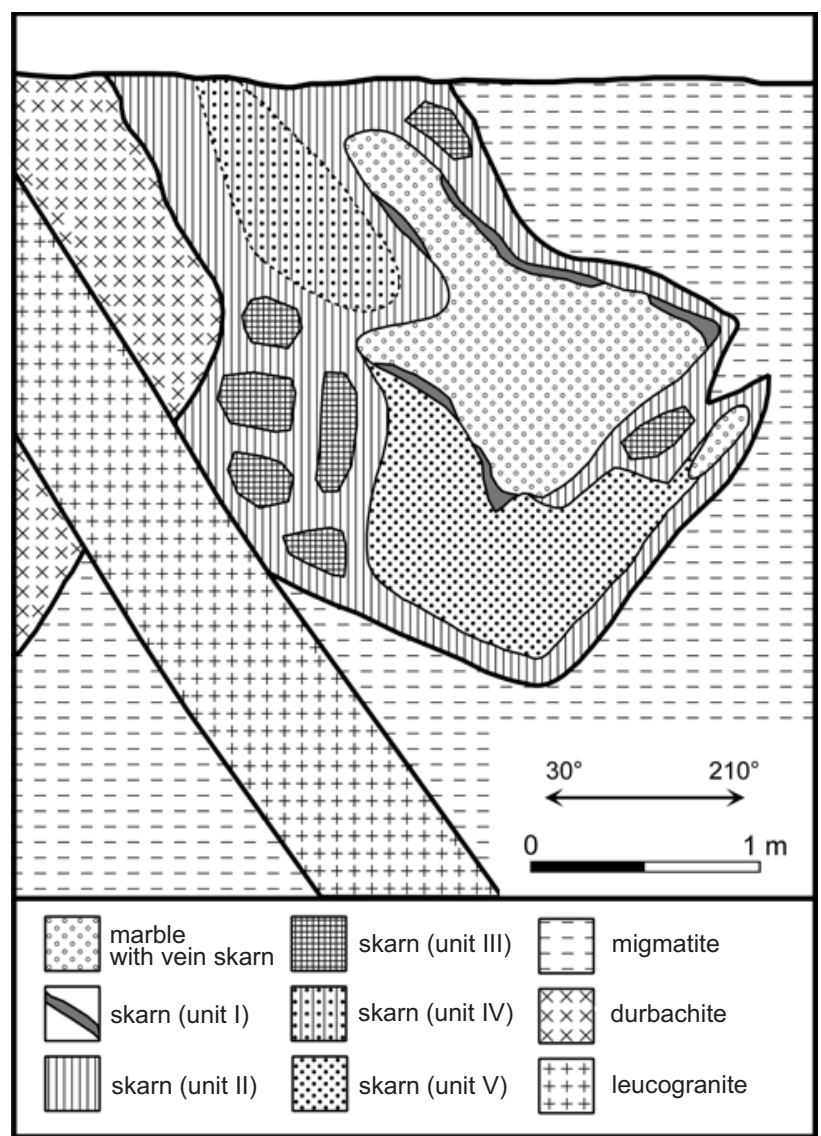

Fig. 3 Cross-section showing the distribution of the marble, skarn and granitoid units.

\subsection{Chondrodite marble}

The main marble body, $c .1 .5 \times 1.5 \mathrm{~m}$ in size, was enclosed in skarn and represents a relic of the originally much larger marble lens. It was cut by thin veins of hedenbergite described below. Greyish white, coarsegrained marble contains grains of yellow chondrodite

Tab. 1 Review of minerals occurring in the marble and various types of skarns

\begin{tabular}{|c|c|c|c|c|c|}
\hline \multirow[t]{2}{*}{ Rock type } & & \multirow[t]{2}{*}{ marble } & \multicolumn{3}{|c|}{ skarn } \\
\hline & & & vein & massive & $\begin{array}{l}\text { sulphide- } \\
\text { rich }\end{array}$ \\
\hline Allanite & Aln & - & - & $\mathrm{x}$ & - \\
\hline Anorthite & An & - & $\mathrm{t}$ & $\mathrm{x}$ & - \\
\hline Arsenopyrite & Apy & - & $\mathrm{t}$ & $\mathrm{x}$ & $\mathrm{X}$ \\
\hline Bismuth & & $\mathrm{t}$ & $\mathrm{t}$ & - & $\mathrm{x}$ \\
\hline $\mathrm{Bi}-\mathrm{Te}$ & & - & $\mathrm{t}$ & - & $\mathrm{x}$ \\
\hline Calcite & Cal & $X$ & $\mathrm{x}$ & - & $\mathrm{x}$ \\
\hline Chalcopyrite & Ccp & - & - & - & $\mathrm{x}$ \\
\hline Clintonite & Cli & $\mathrm{t}$ & - & - & - \\
\hline Diopside & Di & $\mathrm{t}$ & $\mathrm{x}$ & $\mathrm{X}$ & $\mathrm{x}$ \\
\hline Dolomite & Dol & $\mathrm{x}$ & - & - & - \\
\hline Edenite & Ed & $\mathrm{x}$ & $\mathrm{t}$ & - & - \\
\hline Epidote & Ep & - & $\mathrm{x}$ & $\mathrm{t}$ & $\mathrm{x}$ \\
\hline Fe-amphibole & & - & $\mathrm{t}$ & $\mathrm{x}$ & $\mathrm{X}$ \\
\hline Fluorapatite & Ap & $\mathrm{t}$ & $\mathrm{t}$ & $\mathrm{x}$ & - \\
\hline Fluorite & $\mathrm{Fl}$ & $\mathrm{t}$ & - & - & - \\
\hline Grossular & Grs & - & - & $\mathrm{X}$ & - \\
\hline Hedenbergite & Hd & - & $X$ & $\mathrm{X}$ & $\mathrm{X}$ \\
\hline Chlorite & Chl & $\mathrm{x}$ & $\mathrm{t}$ & - & $\mathrm{x}$ \\
\hline Chondrodite & Chn & $X$ & - & - & - \\
\hline K-feldspar & Kfs & - & - & $\mathrm{t}$ & - \\
\hline $\begin{array}{l}\text { Niobian } \\
\text { titanite }\end{array}$ & $\mathrm{Nb}-\mathrm{Ttn}$ & - & $\mathrm{x}$ & $\mathrm{t}$ & - \\
\hline Pargasite & Prg & $\mathrm{x}$ & $\mathrm{t}$ & - & - \\
\hline Phlogopite & Phl & $\mathrm{x}$ & - & $\mathrm{x}$ & $\mathrm{x}$ \\
\hline Prehnite & Prh & - & $\mathrm{x}$ & $\mathrm{t}$ & $\mathrm{t}$ \\
\hline Pyrrhotite & Po & - & $\mathrm{t}$ & $\mathrm{X}$ & $\mathrm{X}$ \\
\hline Pyrite & Py & $\mathrm{t}$ & - & $\mathrm{x}$ & $X$ \\
\hline Quartz & Qtz & - & $\mathrm{x}$ & $\mathrm{x}$ & $\mathrm{x}$ \\
\hline Scheelite & Sch & - & $\mathrm{X}$ & $\mathrm{x}$ & $X$ \\
\hline Siderite & $\mathrm{Sd}$ & - & - & $\mathrm{x}$ & $\mathrm{X}$ \\
\hline Spinel & Spl & $\mathrm{t}$ & - & - & - \\
\hline Titanite & Ttn & - & $\mathrm{t}$ & $\mathrm{t}$ & - \\
\hline Tremolite & $\operatorname{Tr}$ & $\mathrm{t}$ & - & - & - \\
\hline Vesuvianite & Ves & - & - & $\mathrm{x}$ & - \\
\hline Wollastonite & Wo & - & - & $\mathrm{x}$ & - \\
\hline
\end{tabular}

$\mathrm{X}=$ major, $\mathrm{x}=$ minor, $\mathrm{t}=$ trace; abbreviations from Kretz (1983) except for $\mathrm{Cli}=$ clintonite, $\mathrm{Sch}=$ scheelite. $\mathrm{Fe}$-amphibole $=\mathrm{Fe}$-bearing green amphibole (Fe-rich magnesiohornblende and actinolite) 
and phlogopite. Chondrodite forms anhedral grains up to $4 \mathrm{~mm}$ in size, associated with phlogopite, tremolite, diopside, clintonite, spinel and chlorite. It contains inclusions of apatite, pyrrhotite and zircon (?), together with thin younger fluorite veinlets. Chondrodite contains low contents of $\mathrm{Fe}\left(0.080-0.132\right.$ apfu $\left.\mathrm{Fe}^{2+}{ }_{\text {tot }}\right)$ with $\mathrm{Ti}$ (0.014-0.057 apfu $\left.\mathrm{Ti}^{4+}\right)$, and traces of $\mathrm{Mn}(\leq 0.004$ apfu $\left.\mathrm{Mn}^{2+}\right)$ and $\mathrm{Ca}\left(\leq 0.0006\right.$ apfu $\left.\mathrm{Ca}^{2+}\right)$. Its fluorine content (1.110-1.368 apfu $\left.\mathrm{F}, \mathrm{X}_{\mathrm{F}}=56-68\right)$ and MTi/Si ratio (varying from 2.47 to 2.52 ) correspond to pure chondrodite, as confirmed by the X-ray powder diffraction pattern. $\mathrm{Phlogopite}$ is colourless, contains relatively high amount of $\mathrm{F}$ (1.016-1.170 apfu F), low Fe (0.081-0.155 apfu) and $\mathrm{Na}(0.030-0.144$ apfu $)$. Contents of $\mathrm{Ca}, \mathrm{Ba}, \mathrm{Cr}$ and
$\mathrm{Mn}$ are near detection limits. Clintonite forms sheaf-like aggregates $<1 \mathrm{~mm}$, contains relatively high $\mathrm{F}(0.838$ 0.976 apfu $\left.\mathrm{F}, \mathrm{X}_{\mathrm{F}}=20-25\right)$, low Fe $(0.083-0.097$ apfu), $\mathrm{Na}(0.038-0.041$ apfu), K (0.002-0.004 apfu) and Ti (0.005-0.009 apfu). Clintonite is extensively replaced by chlorite II (as noted already by Houzar and Novák 2006). Other silicates are accessoric. Amphibole is of composition corresponding to edenite-pargasite $(6.048-6.552 \mathrm{Si}$, 2.095-2.814 Al, 0.728-0.150 Fe, 0.417-0.780 Na and $0.566-0.631 \mathrm{~F}$, all values are $a p f u)$ or tremolite $(7.95 \mathrm{Si}$, $\leq 0.046 \mathrm{Al}, \leq 0.052 \mathrm{Fe}, \leq 0.034 \mathrm{Na}$ and $\leq 0312 \mathrm{~F}, a p f u$ ). Diopside and spinel are close to their respective $\mathrm{Mg}$ endmembers (Table 2). Fluorapatite, pyrrhotite, pyrite and rare native bismuth up to $20 \mu \mathrm{m}$ in size are accessories.

Tab. 2 Representative chemical compositions of minerals in the marble (chondrodite, amphiboles, phlogopite, clintonite, chlorite, spinel and diopside)

\begin{tabular}{|c|c|c|c|c|c|c|c|c|c|c|c|c|c|}
\hline mineral & Chn & Chn & Chn & Chn & Tr & Ed & Phl & Cli & Cli & Chl & Chl & Spl & Di \\
\hline $\mathrm{SiO}_{2}$ & 34.85 & 34.66 & 34.73 & 35.27 & 58.84 & 47.22 & 43.36 & 20.97 & 19.81 & 30.63 & 30.17 & b.d. & 54.90 \\
\hline $\mathrm{TiO}_{2}$ & 0.22 & 0.33 & 1.33 & 0.33 & 0.05 & 0.12 & 0.06 & 0.05 & 0.08 & 0.02 & 0.11 & 0.03 & 0.06 \\
\hline $\mathrm{Al}_{2} \mathrm{O}_{3}$ & b.d. & b.d. & b.d. & b.d. & 0.29 & 12.81 & 11.97 & 38.03 & 39.87 & 20.75 & 21.83 & 70.74 & 0.20 \\
\hline $\mathrm{Cr}_{2} \mathrm{O}_{3}$ & b.d. & b.d. & b.d. & b.d. & b.d. & b.d. & 0.02 & 0.02 & 0.01 & b.d. & b.d. & 0.03 & b.d. \\
\hline $\mathrm{FeO}$ & 2.33 & 2.40 & 1.86 & 2.77 & 0.46 & 1.29 & 0.45 & 0.71 & 0.83 & 1.47 & 0.94 & 3.90 & 1.80 \\
\hline $\mathrm{MnO}$ & 0.06 & 0.05 & 0.02 & 0.06 & b.d. & 0.03 & b.d. & b.d. & 0.02 & 0.01 & b.d. & 0.03 & 0.15 \\
\hline $\mathrm{MgO}$ & 56.90 & 56.54 & 56.61 & 56.45 & 24.52 & 20.29 & 28.08 & 22.44 & 21.84 & 32.84 & 32.44 & 25.87 & 17.58 \\
\hline $\mathrm{CaO}$ & 0.06 & 0.10 & 0.02 & 0.02 & 13.99 & 14.15 & 0.07 & 13.10 & 13.13 & 0.09 & 0.03 & b.d. & 25.97 \\
\hline $\mathrm{Na}_{2} \mathrm{O}$ & b.d. & b.d. & b.d. & b.d. & 0.13 & 1.55 & 0.26 & 0.14 & 0.15 & b.d. & b.d. & b.d. & 0.02 \\
\hline $\mathrm{K}_{2} \mathrm{O}$ & b.d. & b.d. & b.d. & b.d. & 0.02 & 0.73 & 10.02 & 0.02 & 0.01 & b.d. & b.d. & b.d. & b.d. \\
\hline $\mathrm{H}_{2} \mathrm{O}^{*}$ & 1.65 & 1.79 & 2.23 & 2.33 & 1.87 & 1.55 & 3.03 & 3.25 & 3.40 & 12.44 & 12.59 & - & - \\
\hline $\mathrm{F}$ & 7.54 & 7.20 & 6.35 & 6.16 & 0.73 & 1.29 & 2.64 & 2.21 & 1.90 & 0.55 & 0.24 & b.d. & b.d. \\
\hline $\mathrm{O}=\mathrm{F}$ & -3.17 & -3.03 & -2.67 & -2.59 & -0.31 & -0.54 & -1.11 & -0.93 & -0.80 & -0.23 & -0.10 & - & - \\
\hline Total & 100.44 & 100.04 & 100.48 & 100.80 & 100.60 & 100.49 & 99.04 & 100.00 & 100.25 & 98.57 & 98.25 & 100.76 & 100.75 \\
\hline $\mathrm{Si}^{i^{++}}$ & 1.999 & 1.996 & 1.985 & 2.014 & 7.945 & 6.552 & 6.075 & 2.929 & 2.763 & 2.892 & 2.849 & - & 1.985 \\
\hline $\mathrm{Ti}^{4+}$ & 0.009 & 0.014 & 0.057 & 0.014 & 0.005 & 0.013 & 0.006 & 0.005 & 0.008 & 0.001 & 0.008 & 0.001 & 0.002 \\
\hline $\mathrm{Al}^{3+}$ & - & - & - & - & 0.046 & 2.095 & 1.977 & 6.261 & 6.554 & 2.309 & 2.429 & 1.995 & 0.009 \\
\hline $\mathrm{Cr}^{3+}$ & - & - & - & - & - & - & 0.002 & 0.002 & 0.001 & - & - & 0.001 & - \\
\hline $\mathrm{Fe}^{2+}$ & 0.112 & 0.116 & 0.089 & 0.132 & 0.052 & 0.150 & 0.053 & 0.083 & 0.097 & 0.116 & 0.074 & 0.078 & 0.054 \\
\hline $\mathrm{Mn}^{2+}$ & 0.003 & 0.002 & 0.001 & 0.003 & - & 0.004 & - & - & 0.002 & 0.001 & & 0.001 & 0.005 \\
\hline $\mathrm{Mg}^{2+}$ & 4.865 & 4.855 & 4.824 & 4.806 & 4.936 & 4.197 & 5.865 & 4.673 & 4.541 & 4.623 & 4.566 & 0.923 & 0.947 \\
\hline $\mathrm{Ca}^{2+}$ & 0.004 & 0.006 & 0.001 & 0.001 & 2.024 & 2.104 & 0.011 & 1.961 & 1.962 & 0.009 & 0.003 & - & 1.006 \\
\hline $\mathrm{Na}^{+}$ & - & - & - & - & 0.034 & 0.417 & 0.071 & 0.038 & 0.041 & - & - & - & 0.001 \\
\hline $\mathrm{K}^{+}$ & - & - & - & - & 0.003 & 0.129 & 1.791 & 0.004 & 0.002 & - & - & - & \\
\hline $\mathrm{H}^{+}$ & 0.632 & 0.688 & 0.852 & 0.887 & 1.688 & 1.434 & 2.830 & 3.024 & 3.162 & 7.836 & 7.928 & - & - \\
\hline $\mathrm{F}^{-}$ & 1.368 & 1.312 & 1.148 & 1.113 & 0.312 & 0.566 & 1.170 & 0.976 & 0.838 & 0.164 & 0.072 & - & - \\
\hline Basis & 10 & 10 & 10 & 10 & 24 & 24 & 24 & 24 & 24 & 18 & 18 & 4 & 6 \\
\hline$X_{F}$ & 69 & 66 & 58 & 56 & 16 & 28 & 29 & 24 & 21 & 2 & 1 & - & - \\
\hline $\mathrm{MTi} / \mathrm{Si}$ & 2.50 & 2.50 & 2.51 & 2.47 & - & - & - & - & - & - & - & - & - \\
\hline
\end{tabular}

$\mathrm{H}_{2} \mathrm{O}$ *: content of $\mathrm{H}_{2} \mathrm{O}$ calculated from stoichiometry; phlogopite contains 0.19 wt. \% BaO; spinel 0.12 wt. \% $\mathrm{ZnO}$ in addition. b.d.: bellow detection limit; basis: basis for calculation of empirical formulae $(\mathrm{O}, \mathrm{OH} p f u) ; \mathrm{X}_{\mathrm{F}}=\mathrm{F} /(\mathrm{F}+\mathrm{OH}) ; \mathrm{MTi} / \mathrm{Si}=(\mathrm{Mg}+\mathrm{Fe}+\mathrm{Mn}+\mathrm{Ti}+\mathrm{Ca}) / \mathrm{Si}$ 
The Nb-titanite and Bi-tellurides in Kamenné doly scheelite skarn

\subsection{Massive skarn}

\subsubsection{Unit I: Diopside-garnet (quartz, \pm vesuvianite, \pm wollastonite) skarn}

Skarn of the Unit I forms a discontinuous rim around the marble body. It is predominantly composed of diopside, less abundant garnet and minor quartz. Wollastonite and vesuvianite occur locally along the contact. The unit is usually $2 \mathrm{~cm}$ wide but locally it swells to $10-20 \mathrm{~cm}$. Several associations were observed: $\mathrm{Di}+\mathrm{Wo}, \mathrm{Di}+\mathrm{Grs}$, Di + Ves, Grs + Ves.

The garnet is orange-red, its composition corresponds to $71-80 \%$ Grs, $12-17 \%$ Adr, 4-8 \% Alm, $1.5-3.3 \%$ Sps and $\sim 1 \%$ Prp. Low contents of Ti $(\leq 0.014$ apfu $)$, $\mathrm{P}(\sim 0.002$ apfu $)$, and $\mathrm{F}(\leq 0.029-0.071$ apfu $)$ are characteristic. The garnet grains show a weak zoning with Fe-rich core and a rimward increase in the grossular component. Garnet composition is typical of scheelite-bearing, reduced Ca-skarns (e.g. Shimazaki 1977; Meinert 1992).

Vesuvianite forms brown grains, shortly prismatic crystals up to $3 \mathrm{~mm}$ and small aggregates with garnet, calcite and sericitised $\mathrm{K}$-feldspar. Its composition is characterized by prevalence of iron over magnesium, slightly increased contents of $\mathrm{F}\left(\leq 2.679\right.$ apfu; $\left.\mathrm{X}_{\mathrm{F}}=25-27\right)$, low, but locally elevated $\mathrm{Ti}(\leq 1.187 \mathrm{apfu})$, low $\mathrm{Mn}(\leq 0.07$ $a p f u)$ and $\mathrm{Na}(\leq 0.06 a p f u$; Table 3$)$. Thus it resembles vesuvianite in other Ca-skarns (Groat et al. 1997). Diopside (0.313-0.345 apfu Fe; 0.013-0.014 apfu Mn and 0.004-0.008 apfu Na) has slightly increased content of Al (0.096-0.119 apfu). Vesuvianite is accompanied by brown anhedral titanite, locally niobium-bearing, up to $0.5 \mathrm{~mm}$ in size.

\subsubsection{Unit II: Clinopyroxene-quartz skarn}

The Unit II forms greyish green continuous zone with a variable width $(\leq 2.5 \mathrm{~m})$, at the contacts of both chondrodite marble and skarn Unit I with migmatite and durbachite. With increasing content of sulphides and amphiboles this skarn type passes gradually into Unit IV. Fine-grained, greyish green clinopyroxene $(\leq 0.502$ apfu $\mathrm{Fe} ; \leq 0.022$ apfu $\mathrm{Mn}$ ) skarn rich in quartz contains disseminated sulphides and scheelite. Apatite, titanite and rare allanite are accessoric. Locally occur narrow zones of phlogopite along the contact of the Unit II with marble containing pseudomorphs of serpentine after chondrodite.

\subsubsection{Unit III: Nearly monomineralic clinopyroxene skarn}

Medium-grained, dark green skarn of the Unit III forms isolated enclaves in the Unit II. The contact of both units
Tab. 3 Representative chemical compositions of grossular and vesuvianite in massive skarn.

\begin{tabular}{|c|c|c|c|c|c|c|}
\hline & Grs & Grs & Grs & Grs & Ves & Ves \\
\hline $\mathrm{SiO}_{2}$ & 38.67 & 37.90 & 38.48 & 38.92 & 35.53 & 35.22 \\
\hline $\mathrm{TiO}_{2}$ & 0.25 & 0.03 & 0.02 & 0.12 & 1.90 & 3.14 \\
\hline $\mathrm{Al}_{2} \mathrm{O}_{3}$ & 19.41 & 18.65 & 18.79 & 19.78 & 15.51 & 14.84 \\
\hline $\mathrm{Fe}_{2} \mathrm{O}_{3}^{*}$ & 4.35 & 5.85 & 5.69 & 4.06 & & \\
\hline $\mathrm{FeO}$ & 2.10 & 3.74 & 2.14 & 2.31 & 4.17 & 4.14 \\
\hline $\mathrm{MnO}$ & 0.68 & 1.47 & 1.12 & 0.69 & 0.16 & 0.15 \\
\hline $\mathrm{MgO}$ & 0.34 & 0.24 & 0.30 & 0.32 & 2.07 & 2.00 \\
\hline $\mathrm{CaO}$ & 34.20 & 31.88 & 33.39 & 34.00 & 35.16 & 35.17 \\
\hline $\mathrm{Na}_{2} \mathrm{O}$ & b.d. & b.d. & b.d. & b.d. & 0.06 & 0.05 \\
\hline $\mathrm{P}_{2} \mathrm{O}_{5}$ & 0.03 & 0.03 & 0.03 & 0.02 & 0.02 & 0.03 \\
\hline F & 0.18 & 0.29 & 0.13 & 0.12 & 1.69 & 1.56 \\
\hline $\mathrm{O}=\mathrm{F}$ & -0.08 & -0.12 & -0.05 & -0.05 & -0.71 & -0.66 \\
\hline $\mathrm{H}_{2} \mathrm{O}^{*}$ & & & & & 2.19 & 2.24 \\
\hline Total & 100.13 & 99.96 & 100.04 & 100.30 & 97.75 & 97.91 \\
\hline $\mathrm{Si}^{4^{++}}$ & 2.960 & 2.937 & 2.963 & 2.970 & 17.809 & 17.705 \\
\hline $\mathrm{Ti}^{4+}$ & 0.014 & 0.002 & 0.001 & 0.007 & 0.716 & 1.187 \\
\hline $\mathrm{Al}^{3+}$ & 1.751 & 1.704 & 1.705 & 1.779 & 9.163 & 8.792 \\
\hline $\mathrm{Fe}^{3+}$ & 0.251 & 0.341 & 0.330 & 0.233 & & \\
\hline $\mathrm{Fe}^{2+}$ & 0.134 & 0.243 & 0.138 & 0.148 & 1.748 & 1.740 \\
\hline $\mathrm{Mn}^{2+}$ & 0.044 & 0.096 & 0.073 & 0.045 & 0.068 & 0.064 \\
\hline $\mathrm{Mg}^{2+}$ & 0.039 & 0.028 & 0.034 & 0.036 & 1.547 & 1.499 \\
\hline $\mathrm{Ca}^{2+}$ & 2.805 & 2.647 & 2.754 & 2.780 & 18.883 & 18.943 \\
\hline $\mathrm{Na}^{+}$ & - & - & - & - & 0.058 & 0.049 \\
\hline $\mathrm{P}^{5+}$ & 0.002 & 0.002 & 0.002 & 0.001 & 0.008 & 0.013 \\
\hline $\mathrm{F}^{-}$ & 0.044 & 0.071 & 0.032 & 0.029 & 2.679 & 2.480 \\
\hline $\mathrm{OH}^{-}$ & & & & & 7.321 & 7.520 \\
\hline Basis & 8 & 8 & 8 & 8 & 50 & 50 \\
\hline Grs & 80.1 & 70.7 & 75.5 & 80.7 & & \\
\hline Adr & 12.6 & 17.0 & 16.5 & 11.7 & & \\
\hline Alm & 4.5 & 8.1 & 4.6 & 4.9 & & \\
\hline Sps & 1.5 & 3.3 & 2.3 & 1.5 & & \\
\hline Py & 1.3 & 0.9 & 1.1 & 1.2 & & \\
\hline
\end{tabular}

$\mathrm{H}_{2} \mathrm{O}^{*}$ - calculated from stoichiometry; $\mathrm{Fe}_{2} \mathrm{O}_{3}{ }^{*}$ - calculated using normalization on 8 cations and 12 oxygen atoms; b.d.: below detection limit; basis: basis for calculation of empirical formulae (total of cations; *10 F,OH $p f u$ )

is nearly sharp and weakly mineralized by sulphides and scheelite. This unit consists nearly exclusively of hedenbergite. Some grains show compositional zoning with diopsidic core (0.217-0.345 apfu Fe) containing low $\mathrm{Mn}$ and $\mathrm{Na}(\leq 0.013$ apfu $\mathrm{Mn} ; \leq 0.004$ apfu $\mathrm{Na})$, rimmed by a wide zone of Mg-hedenbergite (0.502-0.780 apfu Fe; 0.022-0.029 apfu Mn, 0.012-0.029 apfu $\mathrm{Al}$ and 0.007 
$a p f u \mathrm{Na}$ ). Thin veinlets of garnet with quartz up to $2 \mathrm{~mm}$ wide penetrated this skarn locally.

\subsubsection{Unit IV: Clinopyroxene-amphibole- scheelite-sulphide mineralized skarn}

Green clinopyroxene skarn of variable composition carries extensive sulphide and scheelite mineralisation. At places the clinopyroxene is replaced extensively by amphibole (actinolite-magnesiohornblende), which forms locally monomineralic aggregates. Few quartz-rich parts contain abundant phlogopite which is mostly absent in other units.

\subsubsection{Unit V: Sulphide-scheelite mineralized skarn}

This unit represents a subtype, which differs from the Unit IV especially by the predominance of sulphides and scheelite over silicates. Pyrite and pyrrhotite are the most abundant sulphides, locally forming aggregates up to several tens of $\mathrm{kg}$. Pyrite forms characteristic granular aggregates with numerous voids. These are coated by fine-grained pyrite crystals associated with abundant acicular aggregates of amphibole. Arsenopyrite in crystals up to $1 \mathrm{~cm}$ across is less abundant.

Scheelite, belonging to early mineral components, forms aggregates or disseminations of subhedral to euhedral crystals, rarely exceeding $5 \mathrm{~mm}$. It is commonly associated with fluorapatite. Scheelite crystals in sulphide matrix (Fig. 4) are white, grey white or grey yellow, in part fractured and corroded. They are surrounded by compact, cataclastic pyrite carrying relics of pyrrhotite

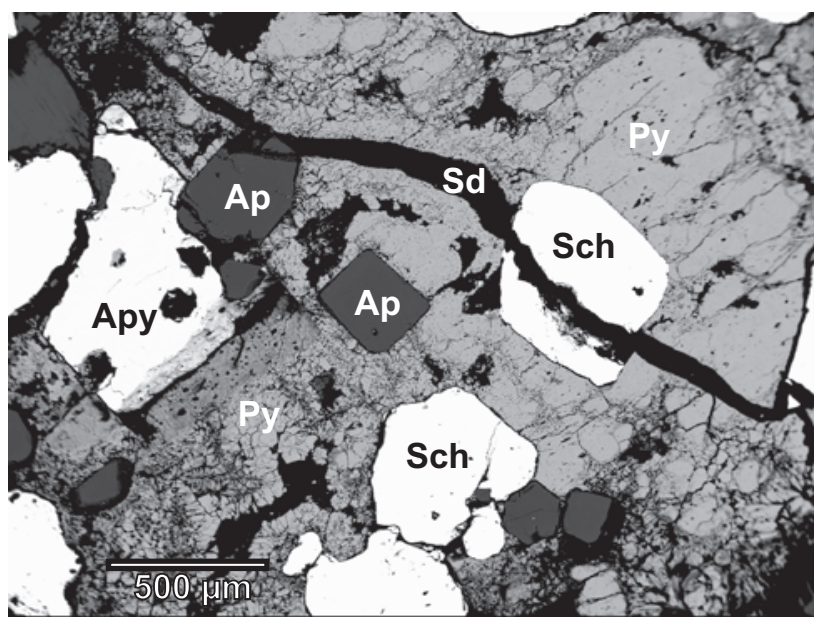

Fig. 4 Mineral assemblage of the scheelite-bearing skarn - Unit V; Apy $=$ arsenopyrite, $\mathrm{Ap}=$ apatite, $\mathrm{Py}=$ pyrite, $\mathrm{Qtz}=$ quartz, $\mathrm{Sch}=$ scheelite (BSE, photo J. Sejkora).

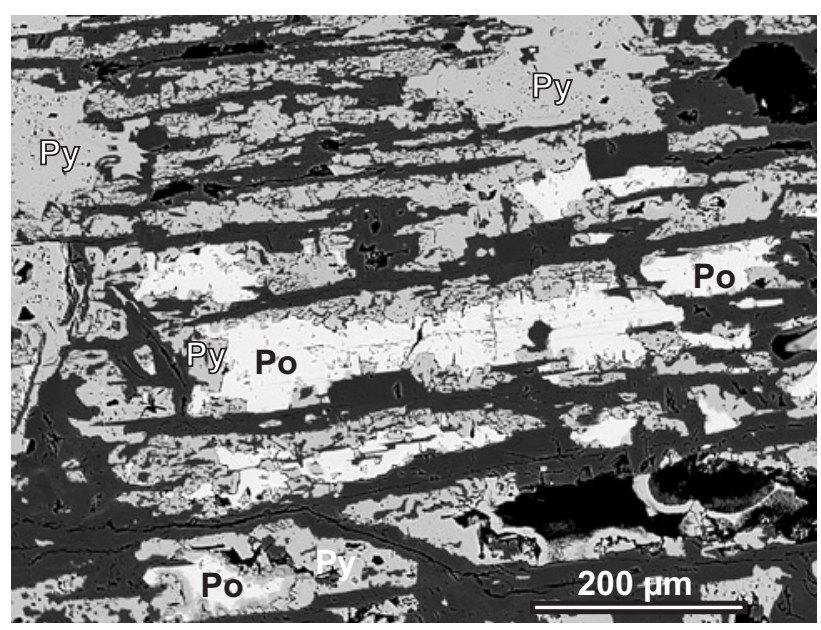

Fig. 5 Pyrrhotite (Po), strongly replaced by pyrite (Py) - skarn Unit V, dark grey to black is siderite (BSE, photo J. Sejkora).

(Fig. 5). The original crystals of pyrrhotite were extensively replaced by pyrite, with replacement starting from grain boundaries and along cleavage planes, resulting in relict zoned structures of the "birds-eye type". Pyrrhotite commonly encloses subhedral fluorapatite and it is locally replaced by minute lobate chalcopyrite. In course of replacement of older silicates by pyrite-pyrrhotite aggregates, abundant prisms of amphibole and brown grossular-rich garnet were enclosed in sulphides. Arsenopyrite forms subhedral grains in the sulphide-scheelite aggregates. In addition to chalcopyrite, arsenopyrite contains microscopic inclusions and irregular aggregates of Bi-minerals, distributed along microfractures. The compact scheelite-sulphide aggregates show abundant effects of brittle deformation. The fractures were filled by dark brown cavernous siderite + quartz veinlets, up to several $\mathrm{cm}$ wide, coated by siderite crystals in small voids. The veinlets sometimes contain rare chalcopyrite.

Chemical composition of homogeneous pyrite, arsenopyrite and chalcopyrite from various assemblages is very close to ideal formulae (Table 4). Among minor elements only $\mathrm{Ag}$ contents reach 0.001 apfu in rare cases. Iron contents in pyrrhotite, after recalculation to $1 \mathrm{~S} a p f u$, correspond to $0.852-0.864 a p f u$. Given the empiric formula of pyrrhotite $\mathrm{Fe}_{1-\mathrm{x}} \mathrm{S}$, this corresponds to $\mathrm{x}=0.14-0.15$. These values fall in the range for natural pyrrhotites, for which $\mathrm{x}=0.00-0.17$ was reported (Anthony et al. 1990). Chemical composition of scheelite (Table 5) corresponds to the ideal end-member $\mathrm{CaWO}_{4}$, which is in agreement with the observed light blue fluorescence under shortwave ultraviolet radiation (e.g. Sato 1982) (Fig. 6). The content of powellite component $\left(\mathrm{WMo}_{-1}\right.$ isomorphism) and of minor elements ( $\mathrm{Fe}, \mathrm{Mn}, \mathrm{Nb}, \mathrm{Ti}, \mathrm{Al}, \mathrm{Sc}, \mathrm{Y}, \mathrm{REE}$ and $\mathrm{Hf}$ ) are below detection limits (c. 0.01-0.03 wt. \%). Co-existing fluorapatite contains very low amounts of $\mathrm{Fe}$ 
Tab. 4 Representative chemical compositions of sulphide minerals

\begin{tabular}{|c|c|c|c|c|c|c|c|}
\hline & pyrite & pyrrhotite & pyrrhotite & arsenopyrite & arsenopyrite & chalcopyrite & chalcopyrite \\
\hline $\mathrm{Ag}$ & 0.04 & 0.03 & 0.04 & 0.05 & 0.07 & 0.02 & 0.05 \\
\hline $\mathrm{Fe}$ & 46.51 & 59.05 & 59.14 & 34.56 & 33.77 & 31.27 & 30.70 \\
\hline $\mathrm{Ni}$ & 0.01 & 0.00 & 0.00 & 0.00 & 0.01 & 0.00 & 0.00 \\
\hline Co & 0.00 & 0.00 & 0.00 & 0.05 & 0.05 & 0.00 & 0.00 \\
\hline $\mathrm{Zn}$ & 0.00 & 0.00 & 0.00 & 0.00 & 0.00 & 0.02 & 0.05 \\
\hline $\mathrm{Cu}$ & 0.00 & 0.00 & 0.00 & 0.00 & 0.00 & 33.96 & 34.17 \\
\hline As & 0.00 & 0.00 & 0.00 & 45.41 & 46.62 & 0.00 & 0.00 \\
\hline $\mathrm{S}$ & 53.73 & 39.80 & 39.28 & 19.93 & 18.70 & 34.82 & 35.28 \\
\hline Total & 100.30 & 98.88 & 98.46 & 99.99 & 99.22 & 100.09 & 100.24 \\
\hline $\mathrm{Ag}$ & 0.000 & 0.000 & 0.000 & 0.001 & 0.001 & 0.000 & 0.001 \\
\hline $\mathrm{Fe}$ & 0.996 & 0.852 & 0.864 & 1.005 & 1.001 & 1.027 & 1.005 \\
\hline $\mathrm{Ni}$ & 0.000 & 0.000 & 0.000 & 0.000 & 0.000 & 0.000 & 0.000 \\
\hline Co & 0.000 & 0.000 & 0.000 & 0.001 & 0.001 & 0.000 & 0.000 \\
\hline $\mathrm{Zn}$ & 0.000 & 0.000 & 0.000 & 0.000 & 0.000 & 0.001 & 0.001 \\
\hline $\mathrm{Cu}$ & 0.000 & 0.000 & 0.000 & 0.000 & 0.000 & 0.980 & 0.983 \\
\hline As & 0.000 & 0.000 & 0.000 & 0.984 & 1.030 & 0.000 & 0.000 \\
\hline$\Sigma$ & 0.996 & 0.852 & 0.865 & 1.991 & 2.034 & 2.008 & 1.989 \\
\hline$S$ & 2.004 & 1.000 & 1.000 & 1.009 & 0.966 & 1.992 & 2.011 \\
\hline Basis & 3 & $1^{*}$ & $1^{*}$ & 3 & 3 & 4 & 4 \\
\hline
\end{tabular}

Basis: basis for calculation of empirical formulae; *: pyrrhotite was calculated on the basis of $1 \mathrm{~S}$ apfu.

$\mathrm{Pb}, \mathrm{Cd}, \mathrm{In}, \mathrm{Hg}, \mathrm{Sb}, \mathrm{Bi}$, Se and Te were also analyzed but their contents were bellow detection limits (c. 0.01-0.02 wt. \%)

and Mn, up to 0.01 apfu. The lower content of $\mathrm{P}$ and low sum of oxides (Table 5) suggest the presence of a minor $\left(\mathrm{CO}_{3}\right)^{2-}$ group or other unanalyzed elements (e.g. As, S or V) in the fluorapatite crystal structure.

\subsection{Hedenbergite vein skarn with niobian titanite}

Discordant and conformable veins of hedenbergite skarn in chondrodite marble are considered as an independent skarn type. The small veins only $3 \mathrm{~cm}$ wide are heterogranular, composed dominantly of hedenbergite $(0.539-0.808$ apfu $\mathrm{Fe})$ with a diminutive proportion of the johansenite component (0.033-0.050 apfu Mn), low $\mathrm{Al}(0.009-0.024$ apfu), $\mathrm{Na}(0.002-0.006$ apfu) and Zn (0.002-0.007 apfu). Individual grains show a weak compositional zoning with more magnesian cores (0.5390.651 apfu Fe; Table 6). Anorthite replaced by prehnite, calcite, minor K-feldspar, obviously younger actinolitic amphibole and quartz with Fe-chlorite is uncommon. Accessory minerals include epidote, pyrrhotite, pyrite, apatite, scheelite, niobian titanite, arsenopyrite and grains of native Bi up to $20 \mu \mathrm{m}$.

Some of the skarn veins exhibit weak symmetrical zoning. A central fuzzy zone, less than $3 \mathrm{~mm}$ wide, contains scheelite predominating over silicates and sulphides. Altered anorthite, quartz and sulphides occur near the central zone. Nearly the whole volume of veins is occupied by hedenbergite, which shows a slightly more magnesian composition toward wallrock marble. Directly at the contact occurs a yellowish, nearly pure diopside $(\leq 0.046 \mathrm{Fe} ; \leq 0.003 \mathrm{Mn} ; \leq 0.031 \mathrm{Al}$ and $\leq 0.001 \mathrm{Na}$, all values in apfu) accompanied by calcite and quartz.

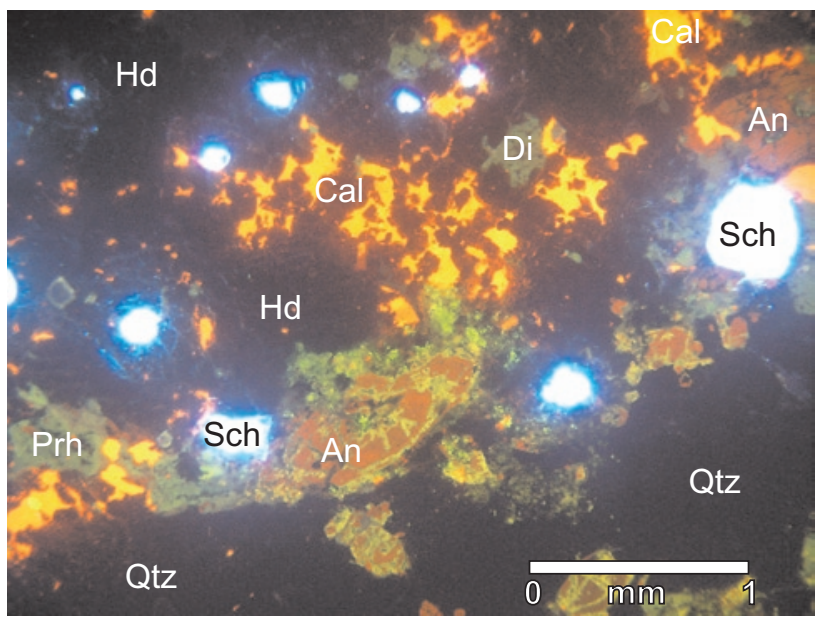

Fig. 6 Mineral assemblage in the vein skarn; An = anorthite, $\mathrm{Cal}=$ calcite, $\mathrm{Di}=$ diopside, $\mathrm{Hd}=$ hedenbergite, $\mathrm{Qtz}=$ quartz, $\mathrm{Prh}=$ prehnite, $\mathrm{Sch}=$ scheelite (optical cathodoluminescence, photo J. Leichmann). 
Tab. 5 Representative chemical compositions of scheelite and fluorapatite

\begin{tabular}{|c|c|c|c|c|c|}
\hline \multirow[b]{2}{*}{$\mathrm{CaO}$} & \multicolumn{3}{|c|}{ scheelite } & \multicolumn{2}{|c|}{ fluorapatite } \\
\hline & 19.89 & 19.89 & 19.87 & 55.24 & 56.47 \\
\hline $\mathrm{FeO}$ & 0.03 & 0.00 & 0.01 & 0.12 & 0.04 \\
\hline $\mathrm{MnO}$ & 0.00 & 0.00 & 0.00 & 0.12 & 0.04 \\
\hline $\mathrm{SiO}_{2}$ & 0.00 & 0.00 & 0.00 & 0.06 & 0.03 \\
\hline $\mathrm{P}_{2} \mathrm{O}_{5}$ & 0.00 & 0.00 & 0.00 & 39.35 & 39.98 \\
\hline $\mathrm{As}_{2} \mathrm{O}_{3}$ & 0.03 & 0.02 & 0.01 & - & - \\
\hline $\mathrm{MoO}_{3}$ & 0.01 & 0.00 & 0.00 & - & - \\
\hline $\mathrm{WO}_{3}$ & 79.72 & 80.09 & 79.49 & - & - \\
\hline $\mathrm{Cl}$ & - & - & - & 0.02 & 0.01 \\
\hline $\mathrm{F}$ & - & - & - & 3.32 & 3.34 \\
\hline $\mathrm{H}_{2} \mathrm{O}^{*}$ & - & - & - & 0.20 & 0.23 \\
\hline $\mathrm{O}=\mathrm{F}$ & - & - & - & -1.40 & -1.41 \\
\hline Total & 99.65 & 100.0 & 99.38 & 97.03 & 98.73 \\
\hline $\mathrm{Ca}^{2+}$ & 1.015 & 1.013 & 1.016 & 4.983 & 4.994 \\
\hline $\mathrm{Fe}^{2+}$ & 0.001 & 0.000 & 0.000 & 0.008 & 0.003 \\
\hline $\mathrm{Mn}^{2+}$ & 0.000 & 0.000 & 0.000 & 0.009 & 0.003 \\
\hline$\Sigma$ & 1.016 & 1.013 & 1.016 & 5.000 & 5.000 \\
\hline $\mathrm{Si}^{4+}$ & 0.000 & 0.000 & 0.000 & 0.005 & 0.002 \\
\hline $\mathrm{P}^{5+}$ & 0.000 & 0.000 & 0.000 & 2.805 & 2.794 \\
\hline $\mathrm{As}^{3+}$ & 0.001 & 0.001 & 0.000 & - & - \\
\hline $\mathrm{Mo}^{6+}$ & 0.000 & 0.000 & 0.000 & - & - \\
\hline $\mathrm{W}^{6+}$ & 0.983 & 0.986 & 0.984 & - & - \\
\hline$\Sigma$ & 0.984 & 0.987 & 0.984 & 2.810 & 2.796 \\
\hline $\mathrm{Cl}^{-}$ & - & - & - & 0.003 & 0.001 \\
\hline $\mathrm{F}^{-}$ & - & - & - & 0.884 & 0.872 \\
\hline $\mathrm{OH}$ & - & - & - & 0.113 & 0.127 \\
\hline$\Sigma$ & - & - & - & 1.000 & 1.000 \\
\hline Basis & 2 & 2 & 2 & $5^{* *}$ & $5^{* *}$ \\
\hline
\end{tabular}

$\mathrm{H}_{2} \mathrm{O}^{*}$ - calculated from stoichiometry;

Basis: basis for calculation of empirical formulae

** calculated on basis $(\mathrm{Ca}+\mathrm{Fe}+\mathrm{Mn})=5 a p f u$.

\section{Mineralizations studied}

\subsection{Niobian titanite}

\subsubsection{Massive skarn (Unit I)}

Rare anhedral grains of titanite with variable $\mathrm{Nb}$ contents are present in vesuvianite of the skarn Unit I (Fig. 7). Titanite has a complicated zoning with elevated content of $\mathrm{Al}(0.084-0.169$ apfu) and variable but slightly increased contents of $\mathrm{Nb}\left(0.22-1.90\right.$ wt. $\% \mathrm{Nb}_{2} \mathrm{O}_{5} ; 0.003-0.028$ apfu $\mathrm{Nb}), \operatorname{Sn}(0.002-0.006$ apfu), Zr (0.003-0.011 apfu), F (0.032-0.106 apfu) and minor Ta (0-0.002 apfu). The maximum values for several elements listed above can be considered as anomalous if compared to compositions of titanite in calc-silicate rocks (see the review in Bernau and Franz 1987).

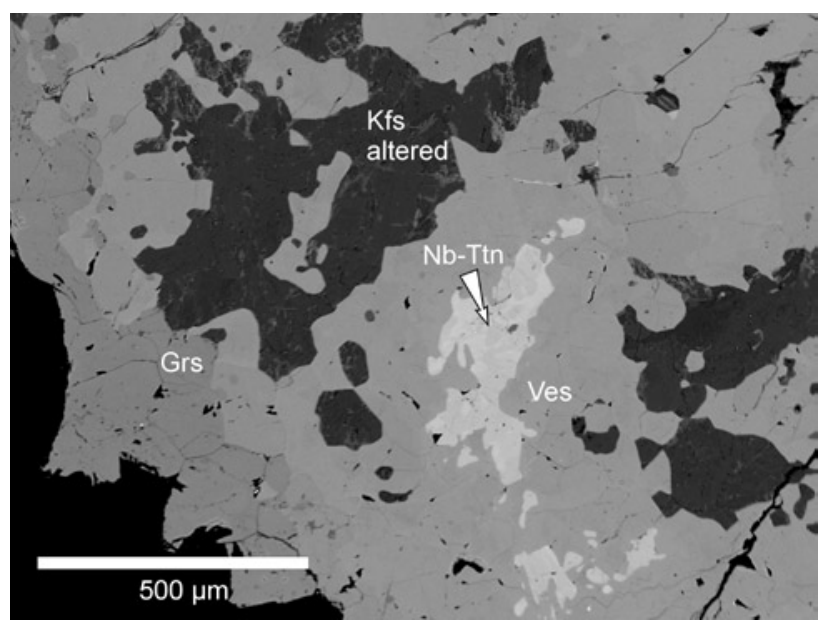

Fig. 7 Niobian titanite (Nb-Ttn) in garnet-vesuvianite skarn - Unit I (BSE, photo R. Škoda).

\subsubsection{Vein skarn}

Niobian titanite forms anhedral grains less than $0.3 \mathrm{~mm}$ across, showing irregular compositional zoning. Unidentified $\mathrm{Ca}-\mathrm{Nb}$ oxides form very rare inclusions in titanite, too small $(\leq 1 \mu \mathrm{m})$ to be analyzed with electron microprobe. Apart from elevated niobium (1.11-10.6 wt. \% $\mathrm{Nb}_{2} \mathrm{O}_{5}$; 0.014-0.164 apfu $\mathrm{Nb}$ ) and extremely variable Ta contents (0.16-4.07 wt. \% $\mathrm{Ta}_{2} \mathrm{O}_{5} ; 0.002-0.038$ apfu Ta), niobian titanite is relatively rich in $\mathrm{Al}(0.147-0.253 a p f u)$. Locally it contains slightly increased amounts of Fe (0.012-0.040 apfu), F (0.055-0.185 apfu) and Sn (0.007-0.017 apfu). In contrast to the titanite from massive skarn, the titanite from vein skarn is poor in $\operatorname{Zr}(0.000-0.002$ apfu). Contents of $\mathrm{Na}, \mathrm{Mg}$ and $\mathrm{Mn}$ are below detection limits (Table 7). Individual grains show an irregular patchy zoning with $\mathrm{Nb}$ and Fe decreasing toward margins, where the composition is more homogeneous and closer to the ideal titanite endmember (Figs 8 and 9).

\subsection{Native bismuth and Bi-tellurides}

Besides traces of microscopic native bismuth in marble near skarn veins, the Unit $\mathrm{V}$ contains microscopic inclusions and irregular aggregates of Bi-minerals, distributed along microfractures in chalcopyrite and arsenopyrite in massive skarn. Native bismuth containing up to 0.07 apfu Fe and 0.03 apfu Sb (Table 8) forms metasomatic aggregates (up to $0.12 \times 0.015-0.030 \mathrm{~mm}$ ) with good cleavage. Very rare Bi-(sulpho-) tellurides were found as irregular aggregates up to $1-5 \mu \mathrm{m}$ in size in microfractures of arsenopyrite grains. At the studied locality, two members of this system were identified. The first Bi-(sulpho-) telluride with empiric formula $\mathrm{Bi}_{1.98}\left(\mathrm{Te}_{0.66} \mathrm{~S}_{0.34} \mathrm{Se}_{0.02}\right)_{\Sigma 1.02}$ (average of 2 analyses, based on 3 apfu) is obviously 
Tab. 6 Representative chemical compositions of ferromagnesian minerals in skarn (pyroxenes and amphiboles)

\begin{tabular}{|c|c|c|c|c|c|c|c|c|c|c|c|c|}
\hline & Hd & Hd & Di & Di & Hd & Hd & Di & Hd & Prg & Hbl & Ed & $\operatorname{Tr}$ \\
\hline & vein & vein & vein & Unit I & Unit I & Unit II & Unit III(c) & Unit III(r) & vein & Unit IV & Unit IV & Unit IV \\
\hline $\mathrm{SiO}_{2}$ & 50.38 & 49.29 & 54.97 & 50.67 & 51.05 & 51.29 & 53.02 & 48.73 & 42.11 & 53.89 & 43.90 & 57.89 \\
\hline $\mathrm{TiO}_{2}$ & 0.01 & 0.03 & 0.06 & 0.31 & 0.03 & 0.01 & 0.04 & 0.03 & 0.11 & 0.11 & 0.16 & 0.24 \\
\hline $\mathrm{Al}_{2} \mathrm{O}_{3}$ & 0.19 & 0.50 & 0.74 & 2.65 & 2.13 & 0.27 & 0.31 & 0.62 & 16.62 & 3.76 & 14.98 & 0.52 \\
\hline $\mathrm{FeO}$ & 21.08 & 24.14 & 1.54 & 9.85 & 10.82 & 15.49 & 6.94 & 23.15 & 6.06 & 1.92 & 2.29 & 3.73 \\
\hline $\mathrm{MnO}$ & 1.47 & 1.47 & 0.11 & 0.41 & 0.43 & 0.66 & 0.31 & 0.86 & 0.20 & 0.04 & 0.05 & 0.37 \\
\hline $\mathrm{MgO}$ & 4.71 & 2.51 & 17.61 & 10.93 & 10.66 & 8.18 & 13.97 & 3.48 & 15.97 & 22.48 & 18.98 & 22.35 \\
\hline $\mathrm{CaO}$ & 23.73 & 23.30 & 26.24 & 24.71 & 24.46 & 24.27 & 25.34 & 23.28 & 13.42 & 13.99 & 13.91 & 13.26 \\
\hline $\mathrm{ZnO}$ & 0.15 & 0.19 & 0.01 & 0.05 & 0.03 & b.d. & 0.05 & 0.08 & 0.07 & 0.05 & b.d. & 0.06 \\
\hline $\mathrm{Na}_{2} \mathrm{O}$ & 0.07 & 0.08 & 0.02 & 0.11 & 0.06 & 0.13 & 0.05 & 0.09 & 2.80 & 1.38 & 2.26 & 0.19 \\
\hline $\mathrm{K}_{2} \mathrm{O}$ & b.d. & b.d. & b.d. & b.d. & b.d. & b.d. & b.d. & b.d. & 0.30 & 0.15 & 0.67 & 0.29 \\
\hline $\mathrm{H}_{2} \mathrm{O}^{*}$ & - & - & - & - & - & - & - & - & 1.43 & 1.58 & 1.25 & 1.87 \\
\hline F & b.d. & b.d. & b.d. & b.d. & b.d. & b.d. & b.d. & b.d. & 1.39 & 1.24 & 1.82 & 0.69 \\
\hline $\mathrm{O}=\mathrm{F}$ & - & - & - & - & - & - & - & - & -0.59 & -0.52 & -0.77 & -0.29 \\
\hline Total & 101.79 & 101.51 & 101.3 & 99.69 & 99.70 & 100.3 & 100.03 & 100.33 & 99.89 & 100.07 & 99.50 & 101.17 \\
\hline $\mathrm{Si}^{4+}$ & 1.981 & 1.973 & 1.974 & 1.924 & 1.944 & 1.987 & 1.979 & 1.963 & 6.048 & 7.458 & 6.221 & 7.905 \\
\hline $\mathrm{Ti}^{4+}$ & - & 0.001 & 0.002 & 0.009 & 0.001 & - & 0.001 & 0.001 & 0.012 & 0.011 & 0.017 & 0.025 \\
\hline $\mathrm{Al}^{3+}$ & 0.009 & 0.024 & 0.031 & 0.119 & 0.096 & 0.012 & 0.014 & 0.029 & 2.813 & 0.613 & 2.502 & 0.084 \\
\hline $\mathrm{Fe}^{2+}$ & 0.693 & 0.808 & 0.046 & 0.313 & 0.345 & 0.502 & 0.217 & 0.780 & 0.728 & 0.222 & 0.271 & 0.426 \\
\hline $\mathrm{Mn}^{2+}$ & 0.049 & 0.050 & 0.003 & 0.013 & 0.014 & 0.022 & 0.010 & 0.029 & 0.024 & 0.005 & 0.006 & 0.043 \\
\hline $\mathrm{Mg}^{2+}$ & 0.276 & 0.15 & 0.943 & 0.619 & 0.605 & 0.472 & 0.777 & 0.209 & 3.419 & 4.638 & 4.010 & 4.550 \\
\hline $\mathrm{Ca}^{2+}$ & 1.000 & 1.000 & 1.009 & 1.005 & 0.998 & 1.007 & 1.013 & 1.005 & 2.065 & 2.074 & 2.112 & 1.940 \\
\hline $\mathrm{Zn}^{2+}$ & 0.004 & 0.006 & - & 0.001 & 0.001 & - & 0.001 & 0.002 & 0.007 & 0.005 & - & 0.006 \\
\hline $\mathrm{Na}^{+}$ & 0.005 & 0.006 & 0.001 & 0.008 & 0.004 & 0.01 & 0.004 & 0.007 & 0.780 & 0.370 & 0.621 & 0.050 \\
\hline $\mathrm{K}^{+}$ & - & - & - & - & - & - & - & - & 0.055 & 0.026 & 0.121 & 0.051 \\
\hline $\mathrm{H}^{+}$ & - & - & - & - & - & - & - & - & 1.369 & 1.457 & 1.184 & 1.702 \\
\hline $\mathrm{F}^{-}$ & - & - & - & - & - & - & - & - & 0.631 & 0.543 & 0.816 & 0.298 \\
\hline Basis & 6 & 6 & 6 & 6 & 6 & 6 & 6 & 6 & 24 & 24 & 24 & 24 \\
\hline $\mathrm{X}_{\mathrm{Fe}}$ & 68 & 80 & 5 & 33 & 36 & 51 & 22 & 77 & 17 & 5 & 6 & 8 \\
\hline
\end{tabular}

$\mathrm{c}=$ core, $\mathrm{r}=$ rim; $\mathrm{H}_{2} \mathrm{O}^{*}-$ calculated from stoichiometry; b.d.: below detection limit; $\mathrm{X}_{\mathrm{Fe}}=\mathrm{Fe} /(\mathrm{Fe}+\mathrm{Mg}+\mathrm{Mn})$; basis: basis for calculation of empirical formulae $(\mathrm{O}, \mathrm{OH} p f u)$

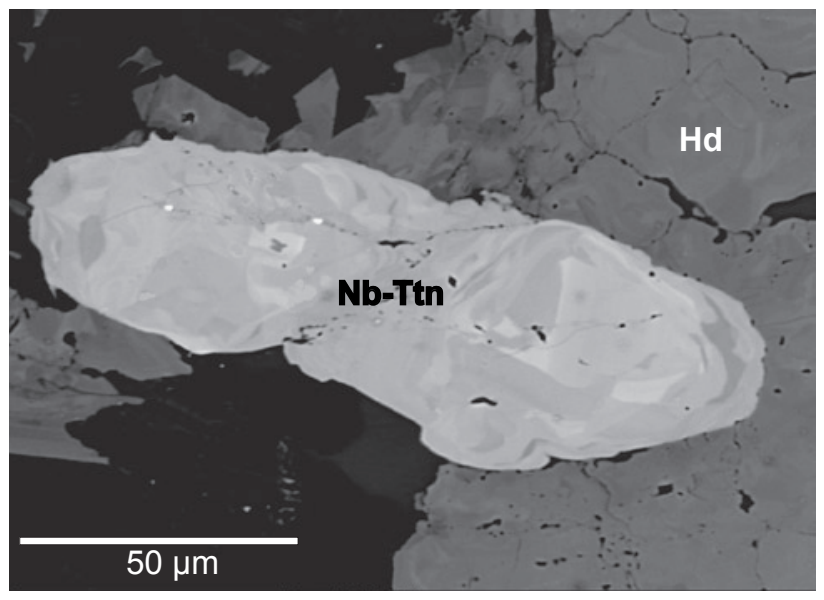

Fig. 8 Patchy-zoned niobian titanite with hedenbergite in vein skarn (BSE, photo R. Škoda).

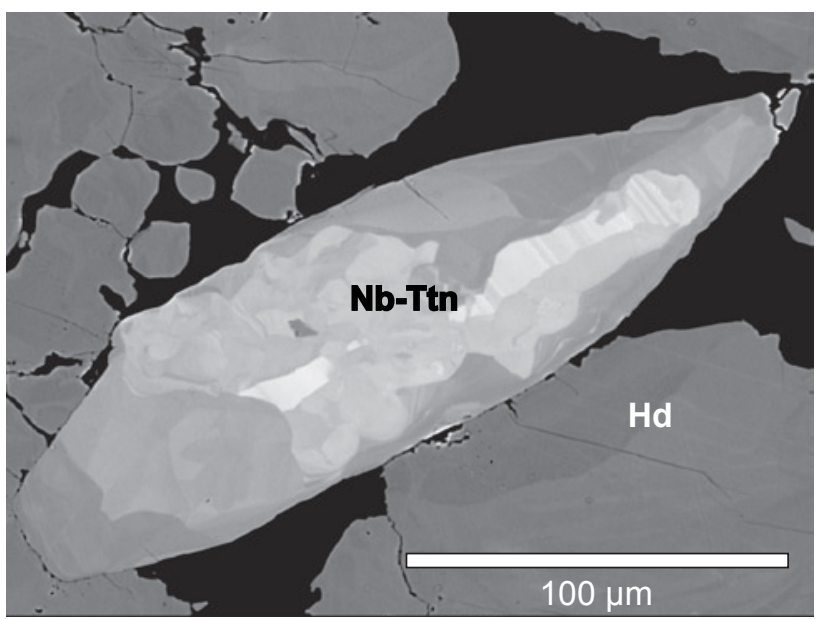

Fig. 9 Patchy-zoned niobian titanite with hedenbergite in vein skarn (BSE, photo R. Škoda). 
Tab. 7 Representative chemical compositions of titanite

\begin{tabular}{|c|c|c|c|c|c|c|c|c|c|c|c|}
\hline \multirow[b]{2}{*}{$\mathrm{SiO}_{2}$} & \multicolumn{6}{|c|}{ vein marble } & \multicolumn{5}{|c|}{ massive skarn (Unit I) } \\
\hline & 29.13 & 29.10 & 29.08 & 29.72 & 28.93 & 29.71 & 29.70 & 29.81 & 30.23 & 29.99 & 30.14 \\
\hline $\mathrm{TiO}_{2}$ & 24.11 & 20.90 & 20.36 & 29.93 & 19.94 & 26.45 & 35.59 & 36.04 & 32.46 & 35.33 & 31.36 \\
\hline $\mathrm{SnO}_{2}$ & 0.82 & 0.55 & 0.59 & 1.29 & 0.64 & 1.04 & 0.23 & 0.30 & 0.43 & 0.20 & 0.41 \\
\hline $\mathrm{ZrO}_{2}$ & 0.03 & 0.07 & 0.05 & 0.13 & 0.04 & 0.07 & 0.32 & 0.30 & 0.48 & 0.69 & 0.40 \\
\hline $\mathrm{Al}_{2} \mathrm{O}_{3}$ & 4.28 & 5.77 & 6.27 & 3.71 & 6.19 & 4.34 & 2.17 & 2.23 & 3.50 & 2.18 & 4.34 \\
\hline $\mathrm{V}_{2} \mathrm{O}_{3}$ & 0.11 & 0.04 & 0.02 & b.d. & 0.06 & b.d. & 0.07 & b.d. & b.d. & 0.03 & 0.06 \\
\hline $\mathrm{Nb}_{2} \mathrm{O}_{5}$ & 7.87 & 9.37 & 10.33 & 2.27 & 10.56 & 6.42 & 0.26 & 0.22 & 1.40 & 0.51 & 1.90 \\
\hline $\mathrm{Ta}_{2} \mathrm{O}_{5}$ & 3.60 & 4.07 & 2.30 & 3.12 & 3.36 & 1.92 & 0.02 & 0.01 & 0.07 & 0.06 & 0.27 \\
\hline $\mathrm{Fe}_{2} \mathrm{O}_{3}$ & 1.56 & 1.44 & 1.33 & 0.75 & 1.54 & 1.02 & 0.49 & 0.43 & 0.45 & 0.44 & 0.56 \\
\hline $\mathrm{MnO}$ & 0.08 & 0.12 & 0.07 & 0.02 & 0.08 & 0.04 & b.d. & b.d. & b.d. & 0.01 & 0.02 \\
\hline $\mathrm{MgO}$ & 0.01 & 0.10 & 0.05 & 0.01 & 0.05 & b.d. & 0.01 & 0.02 & 0.10 & 0.02 & 0.03 \\
\hline $\mathrm{CaO}$ & 27.82 & 27.70 & 27.93 & 28.29 & 27.51 & 28.33 & 28.24 & 28.16 & 28.69 & 28.49 & 28.97 \\
\hline F & 0.51 & 0.83 & 0.91 & 0.79 & 0.81 & 0.74 & 0.69 & 0.30 & 1.01 & 0.70 & 1.21 \\
\hline $\mathrm{O}=\mathrm{F}$ & -0.21 & -0.35 & -0.38 & -0.33 & -0.34 & -0.31 & -0.31 & -0.13 & -0.43 & -0.29 & -0.51 \\
\hline Total & 99.72 & 99.71 & 98.91 & 99.70 & 99.37 & 99.77 & 97.48 & 97.69 & 98.39 & 98.36 & 99.16 \\
\hline $\mathrm{Si}^{4+}$ & 0.976 & 0.975 & 0.969 & 0.980 & 0.979 & 0.979 & 0.981 & 0.987 & 0.979 & 0.982 & 0.970 \\
\hline $\mathrm{Ti}^{4+}$ & 0.608 & 0.527 & 0.510 & 0.742 & 0.508 & 0.655 & 0.885 & 0.898 & 0.791 & 0.870 & 0.759 \\
\hline $\mathrm{Sn}^{4+}$ & 0.011 & 0.007 & 0.008 & 0.017 & 0.009 & 0.014 & 0.003 & 0.004 & 0.005 & 0.003 & 0.005 \\
\hline $\mathrm{Zr}^{4+}$ & 0.000 & 0.001 & 0.001 & 0.002 & 0.001 & 0.001 & 0.005 & 0.005 & 0.007 & 0.011 & 0.006 \\
\hline $\mathrm{Al}^{3+}$ & 0.169 & 0.228 & 0.246 & 0.144 & 0.247 & 0.169 & 0.085 & 0.087 & 0.133 & 0.084 & 0.165 \\
\hline $\mathrm{V}^{3+}$ & 0.003 & 0.001 & 0.000 & 0.000 & 0.002 & 0.000 & 0.002 & 0.000 & 0.000 & 0.001 & 0.002 \\
\hline $\mathrm{Nb}^{5+}$ & 0.119 & 0.142 & 0.156 & 0.034 & 0.162 & 0.096 & 0.004 & 0.003 & 0.020 & 0.007 & 0.028 \\
\hline $\mathrm{Ta}^{5+}$ & 0.033 & 0.037 & 0.024 & 0.028 & 0.031 & 0.017 & 0.000 & 0.000 & 0.001 & 0.000 & 0.002 \\
\hline $\mathrm{Fe}^{3+}$ & 0.039 & 0.036 & 0.033 & 0.019 & 0.039 & 0.025 & 0.012 & 0.011 & 0.011 & 0.011 & 0.014 \\
\hline $\mathrm{Mn}^{2+}$ & 0.001 & 0.002 & 0.001 & 0.000 & 0.001 & 0.000 & 0.000 & 0.000 & 0.000 & 0.000 & 0.000 \\
\hline $\mathrm{Mg}^{2+}$ & 0.001 & 0.005 & 0.003 & 0.001 & 0.003 & 0.000 & 0.000 & 0.001 & 0.005 & 0.001 & 0.001 \\
\hline $\mathrm{Ca}^{2+}$ & 0.999 & 0.995 & 0.997 & 0.999 & 0.997 & 1.000 & 1.000 & 0.999 & 0.995 & 0.999 & 0.999 \\
\hline $\mathrm{F}^{-}$ & 0.054 & 0.087 & 0.096 & 0.082 & 0.087 & 0.077 & 0.072 & 0.074 & 0.104 & 0.072 & 0.124 \\
\hline $\mathrm{O}^{2-}$ & 4.864 & 4.829 & 4.799 & 4.841 & 4.863 & 4.834 & 4.870 & 4.904 & 4.784 & 4.859 & 4.763 \\
\hline
\end{tabular}

b.d.: below detection limit

Empirical formulae were calculated on the basis of $1(\mathrm{Ca}+\mathrm{Mg}) \mathrm{pfu}$

a member of the $\mathrm{Bi}_{2} \mathrm{X}$ series (Cook et al. 2007). The second $\mathrm{Bi}$-(sulpho) telluride with empiric formula $\left(\mathrm{Bi}_{4.51} \mathrm{Fe}_{0.40} \mathrm{Cd}_{0.03} \mathrm{~Pb}_{0.02} \mathrm{Sb}_{0.01} \mathrm{As}_{0.01}\right)_{\Sigma 4.98}\left(\mathrm{Te}_{1.58} \mathrm{~S}_{1.36} \mathrm{Se}_{0.08}\right)_{\Sigma 3.02}$ (based on 8 apfu) is probably a S-rich member of the $\mathrm{Bi}_{5} \mathrm{X}_{3}$ series defined by $\mathrm{Gu}$ et al. (2001).

\section{Discussion}

\subsection{Niobian titanite assemblages in calc-silicate rocks}

\subsubsection{Occurrence and chemistry}

The niobian titanite occurs most typically in peralkaline rocks, with the highest reported content of 16.4 wt. \%
$\mathrm{Nb}_{2} \mathrm{O}_{5}$ (Brigatti et al 2004, Chakhmouradian 2004; Liferovich and Mitchell 2005). Niobian titanite has been reported also from some complex pegmatites (Paul et al. 1981; Černý et al. 1995; Szeleg 2003). There is a single report of elevated $\mathrm{Nb}$ content in titanite from calc-silicate rocks (Bernau and Franz 1987) but this may be because $\mathrm{Nb}$ has been analyzed only exceptionally in this rock association. Harlov et al. (2006) reported 0.03-0.32 wt. \% $\mathrm{Nb}_{2} \mathrm{O}_{5}$ for titanite from an assemblage with epidote and scapolite.

An exceptional example is niobian titanite from garnet-pyroxene-scapolite ( \pm quartz, calcite) rock from the Gebel Umm Shagir complex, Egypt, where a complex of migmatites encloses layers of calc-silicate rocks, marbles and amphibolites (Bernau and Franz 1987). Titanite contains up to 11 wt. $\% \mathrm{Nb}_{2} \mathrm{O}_{5}, 6$ wt. $\% \mathrm{Al}_{2} \mathrm{O}_{3}, 2$ wt. $\% \mathrm{~V}_{2} \mathrm{O}_{3}$, 
Tab. 8 Representative chemical compositions of Bi-bearing minerals

\begin{tabular}{|c|c|c|c|c|c|c|}
\hline & $\mathrm{Bi}$ & $\mathrm{Bi}$ & $\mathrm{Bi}$ & $\mathrm{Bi}-\mathrm{Te}$ & $\mathrm{Bi}-\mathrm{Te}$ & $\mathrm{Bi}-\mathrm{Te}$ \\
\hline $\mathrm{Fe}$ & 1.79 & 2.06 & 0.27 & 1.85 & 0.73 & 0.79 \\
\hline $\mathrm{Pb}$ & 0.00 & 0.00 & 0.00 & 0.39 & 0.05 & 0.05 \\
\hline $\mathrm{Cd}$ & 0.19 & 0.13 & 0.10 & 0.25 & 0.22 & 0.19 \\
\hline $\mathrm{Cu}$ & 0.00 & 0.00 & 0.56 & 0.00 & 0.00 & 0.00 \\
\hline $\mathrm{Sb}$ & 1.77 & 2.17 & 1.49 & 0.09 & 0.77 & 0.82 \\
\hline $\mathrm{Bi}$ & 96.61 & 97.28 & 97.59 & 76.92 & 78.79 & 80.11 \\
\hline As & 0.02 & 0.19 & 0.00 & 0.07 & 0.00 & 0.05 \\
\hline $\mathrm{Se}$ & 0.03 & 0.00 & 0.00 & 0.53 & 0.31 & 0.33 \\
\hline $\mathrm{Te}$ & 0.00 & 0.00 & 0.00 & 16.40 & 16.10 & 16.34 \\
\hline $\mathrm{S}$ & 0.00 & 0.00 & 0.00 & 3.55 & 2.08 & 2.11 \\
\hline Total & 100.40 & 101.83 & 100.01 & 100.05 & 99.04 & 100.78 \\
\hline $\mathrm{Fe}$ & 0.063 & 0.071 & 0.010 & 0.406 & 0.066 & 0.071 \\
\hline $\mathrm{Pb}$ & 0.000 & 0.000 & 0.000 & 0.023 & 0.001 & 0.001 \\
\hline $\mathrm{Cd}$ & 0.003 & 0.002 & 0.002 & 0.027 & 0.010 & 0.008 \\
\hline $\mathrm{Cu}$ & 0.000 & 0.000 & 0.018 & 0.000 & 0.000 & 0.000 \\
\hline $\mathrm{Sb}$ & 0.028 & 0.034 & 0.025 & 0.009 & 0.032 & 0.033 \\
\hline $\mathrm{Bi}$ & 0.905 & 0.888 & 0.946 & 4.510 & 1.906 & 1.902 \\
\hline As & 0.000 & 0.005 & 0.000 & 0.011 & 0.000 & 0.003 \\
\hline$\Sigma$ & 0.999 & 1.000 & 1.000 & 4.987 & 2.015 & 2.018 \\
\hline $\mathrm{Se}$ & 0.001 & 0.000 & 0.000 & 0.082 & 0.020 & 0.020 \\
\hline $\mathrm{Te}$ & 0.000 & 0.000 & 0.000 & 1.575 & 0.638 & 0.635 \\
\hline $\mathrm{S}$ & 0.000 & 0.000 & 0.000 & 1.356 & 0.328 & 0.326 \\
\hline$\Sigma$ & 0.001 & 0.000 & 0.000 & 3.013 & 0.985 & 0.982 \\
\hline Basis & 1 & 1 & 1 & 8 & 3 & 3 \\
\hline
\end{tabular}

Basis: basis for calculation of empirical formulae

and traces of Ta, Sn and F. Characteristic is a complex zoning, with $\mathrm{Nb}$ decreasing from core to margin of crystals, less than $1 \mathrm{~mm}$ long. It is enclosed in garnet $\left(\mathrm{Grs}_{62-74}\right.$, $\left.\mathrm{Adr}_{18-30}\right)$, clinopyroxene $\left(\mathrm{Hd}_{40}\right)$ and scapolite (meionite ${ }_{85-}$ ${ }_{88}$ ). The $\mathrm{Nb}$-titanite contains rare inclusions of zircon and $\mathrm{Nb}$-Fe oxide mineral of wodginite-ixiolite type. The rock is interpreted as a product of high-grade metamorphism of a marly limestone protolith. Niobium was presumably present in rare accessory minerals. During the first stage of metamorphism, wodginite-ixiolite was formed and preserved as relics in the core of titanite crystals. Niobian titanite is considered to be a prograde phase (granulite-facies), whereas retrograde metamorphism (amphibolite-facies) could have led to crystallisation of crystal rims with lower $\mathrm{Nb}$ content and elevated $(\mathrm{Al}+\mathrm{OH}, \mathrm{F})$ components. Bernau and Franz (1987) suggested that the presence of niobian titanite reflects an unusual protolith composition, rather than unusual P-T conditions of crystallisation. Regardless of the different geological position, the mineral assemblage and compositional zoning of niobian titanite from Egypt are similar to the situation at the studied locality. However, no additional record of niobian titanite (with $\mathrm{Nb}_{2} \mathrm{O}_{5}>0.5$ wt. \%) in skarnoid rocks has been found in the literature.

Negative correlations of $\mathrm{Al}+\mathrm{F}$ with $\mathrm{R}^{4+}$ and $\mathrm{Al}+\left(\mathrm{Nb}^{5+}\right.$, $\mathrm{Ta}^{5+}$ ) with $\mathrm{R}^{4+}$ (Fig. 10) as well as low contents of $\mathrm{Na}$ in titanite and niobian titanite correspond to the substitutions $\mathrm{Al}(\mathrm{OH}, \mathrm{F})(\mathrm{TiO})_{-1}$ and $(\mathrm{Nb}, \mathrm{Ta}) \mathrm{AlTi}_{-2}$. The first one is dominant in ordinary Nb-poor titanite from skarn Unit I (see also Table 7) and incorporation of $\mathrm{Al}$ into titanite depends mainly on composition of the mineral assemblage. The role of P-T conditions, on the other hand, is of a lesser importance. It is favourably affected by an increased activity of $\mathrm{F}$ and $\mathrm{H}_{2} \mathrm{O}$ (e. g. Novák et al. 1990; Sengupta et al. 2004; Harlov et al. 2006). The second substitution is dominant in niobian titanite from the vein skarn in the marble. According to Černý et al. (1995) it represents the most important mechanism for $\mathrm{Nb}^{5+}$ or $\mathrm{Ta}^{5+}$ incorporation into titanite structure. The PTX conditions for entry of $\mathrm{Nb}$ into titanite lattice remain unconstrained. Niobian titanite has probably an extensive stability field from granulite- and amphibolite-facies (Bernau and Franz 1987) up to conditions of low-temperature "hydrothermal" stage in pegmatites (Černý et al. 1995; Szeleg 2003). Experimental synthesis of niobian titanite at ambient pressure yielded $\mathrm{Nb}$ contents up to 0.25 apfu in case of Al-Nb titanite and up to 0.22 apfu in $\mathrm{Na}-\mathrm{Nb}$ titanite. Experimental data suggest that the existence of a titanite with more than $50 \mathrm{~mol} . \%$ of the $\mathrm{NaNbOSiO}_{4}$ end-member is unlikely (Liferovich and Mitchell 2006).

\subsubsection{Niobium in calc-silicate rocks and metacarbonates}

Only little information is available on abundance of $\mathrm{Nb}$ in both calc-silicate rocks (skarns) and metacarbonates. Newberry (1998) published $\mathrm{Nb}$ contents in some W- and Sn-skarns as averages of individual determinations (whole-rock analyses). Reduced W-skarns contain 17-27 ppm Nb, oxidised skarns 3-43 ppm Nb and skarns of the F-W type 13-103 ppm Nb. The highest content of $103 \mathrm{ppm} \mathrm{Nb}$ was reported from the Pine Creek W-skarn deposit in California, USA.

Analytical data for $\mathrm{Nb}$ in contact skarns and (meta-) carbonate rocks from the Moldanubian Zone of the Bohemian Massif are rather scarce. Scheelite-free skarnoids from Nedvědice contain less than $18 \mathrm{ppm} \mathrm{Nb}$ (Houzar et al. 2006). Exceptionally high content of $393 \mathrm{ppm}$ $\mathrm{Nb}$ has been determined in marble with carbonatitelike compositional tendencies at Muckov and Bližná in southern Bohemia (Drábek et al. 1999). To some extent similar metacarbonates from western Moravia (Houzar and Novák 2002) contain 8-21 ppm Nb. However, Nb content in titanite from these marbles is unknown. In both cases increased Mo content has been found (Šarbach et al. 1985; Drábek et al. 1999; Houzar 2004). 

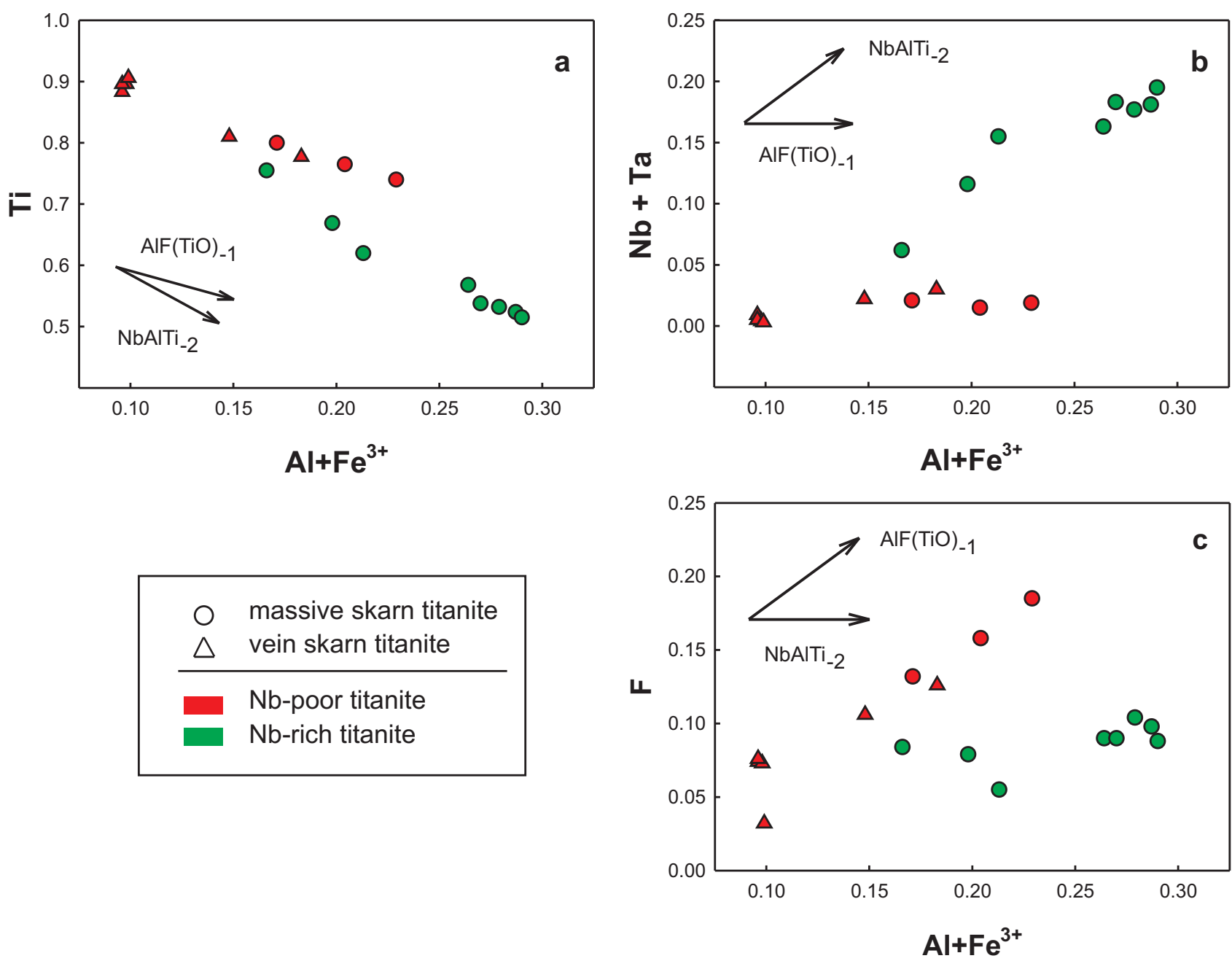

Fig. 10 Crystal chemistry of the Nb-titanite. $\mathbf{a}-\mathrm{Al}+\mathrm{Fe}^{3+}$ vs. Ti plot; $\mathbf{b}-\mathrm{Al}+\mathrm{Fe}^{3+} \mathrm{vs}$. $\mathrm{Nb}+\mathrm{Ta}$ plot; $\mathbf{c}-\mathrm{Al}+\mathrm{Fe}{ }^{3+} \mathrm{vs}$. F plot. Relevant substitution vectors are also shown.

In Kamenné Doly, titanite in massive Grs-Hd skarn replacing marble (Unit I) contains relatively low $\mathrm{Nb}(\leq 1.9$ wt. $\% \mathrm{Nb}_{2} \mathrm{O}_{5}$ ), whereas $\mathrm{Nb}$-rich titanite (1.11-10.56 wt. $\% \mathrm{Nb}_{2} \mathrm{O}_{5}$, average 6.31 wt. $\% \mathrm{Nb}_{2} \mathrm{O}_{5}$ ) is present in vein skarn relatively rich in $\mathrm{Fe}$. The source of $\mathrm{Nb}$ in this case was most probably not in the marble. Niobium seems to have been introduced to the system by Fe- and Si-rich skarn fluids, which interacted with the magmatic rocks in proximity of the marble-skarn enclave.

\subsection{Sulphide - scheelite - Bi-Te mineralization}

Of particular interest is the composition of Bi tellurides, belonging to Bi-rich members of the system $\mathrm{Bi}-\mathrm{Te}-(\mathrm{S}-$ $\mathrm{Se}$ ) (Fig. 11). Similar Bi-rich members, close to hedleyite $\mathrm{Bi}_{8} \mathrm{Te}_{3}$, occur as a part of an assemblage with native bismuth and sulphides in marbles at Nedvědice, Svratka Crystalline Complex, Moldanubian Zone (Houzar et al. 2006). The first Bi-(sulpho) telluride with empiric formula $\mathrm{Bi}_{1.98}\left(\mathrm{Te}_{0.66} \mathrm{~S}_{0.34} \mathrm{Se}_{0.02}\right)_{\Sigma 1.02}$ belongs to the $\mathrm{Bi}_{2} \mathrm{X}$ series, whose members were described from numerous localities as unnamed minerals (Cook et al. 2007). In contrast to the published data ( $\mathrm{Gu}$ et al. 2001; Cook et al. 2007) this phase contains increased content of $\mathrm{S}$ in the anion group, up to 0.33 apfu (Fig. 12). The second $\mathrm{Bi}$-(sulpho) telluride with empiric formula $\left(\mathrm{Bi}_{4.51} \mathrm{Fe}_{0.40} \mathrm{Cd}_{0.03} \mathrm{~Pb}_{0.02} \mathrm{Sb}_{0.01} \mathrm{As}_{0.01}\right)_{\Sigma 4.98}\left(\mathrm{Te}_{1.58} \mathrm{~S}_{1.36} \mathrm{Se}_{0.08}\right)_{\Sigma 3.02}$ is probably a $\mathrm{S}$-rich member of the $\mathrm{Bi}_{5} \mathrm{X}_{3}$ series defined by $\mathrm{Gu}$ et al. (2001). Recently published data corresponding to stoichiometry $\mathrm{Bi}: \mathrm{X}=5: 3$ are commonly designated using incorrect mineral names pilsenite, Bi-pilsenite or Se-rich joseite B (Dimitrova and Kerestedjian 2006; Gu et al. 2001). Both Bi-tellurides $-\mathrm{Bi}_{2} \mathrm{Te}$ and $\mathrm{Bi}_{5} \mathrm{Te}_{3}$ - have been also found in $\mathrm{Au}$-bearing mineral assemblages at the Kašperské Hory and Petráčkova hora deposits (Litochleb and Šrein 1994). 

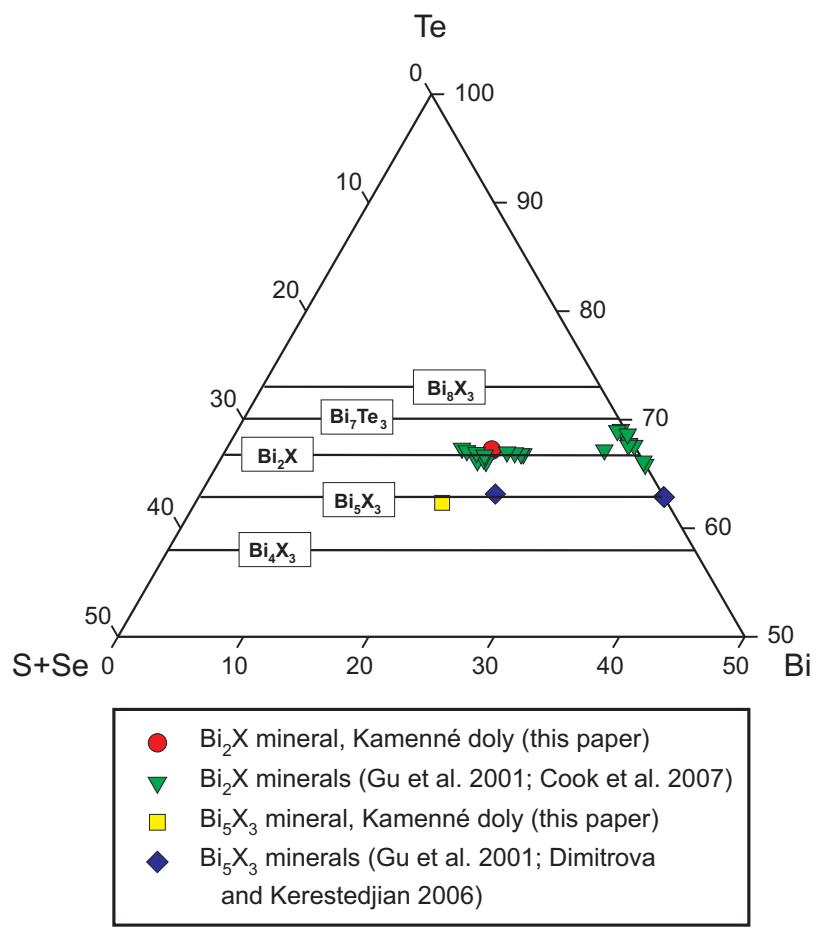

Fig. 11 Part of ternary plot $(\mathrm{S}+\mathrm{Se})-\mathrm{Te}-\mathrm{Bi}$ for Bi-Te minerals from Kamenné doly.

Scheelite is abundant in Units IV and V, to a lesser extent in other skarn units. It is always associated with sulphides. In some cases scheelite forms 30-50 vol. \% of the assemblage, mainly in domains of fine-grained pyrite or in phlogopite-rich skarn (pyrite, phlogopite, scheelite, quartz) in Unit IV. Scheelite is intergrown with actinolite, phlogopite, quartz and sulphides.

Textures and structures of strongly mineralized skarns (scheelite-sulphide) indicate recurrent deformation (cataclastic, brittle deformation) and mineralization. The ore assemblages are characterised by the association of scheelite with sulphides, intense replacement of pyrrhotite by pyrite (but preserving the relict structures) and formation of arsenopyrite metacrysts. Worth nothing is also the presence of Bi-minerals inclusions and the youngest siderite veinlets with drusy cavities, which cut the mineralized skarn as a product of the latest hydrothermal phase.

\subsection{Skarn origin}

Mineral composition, evolution of mineral assemblages, geological position and zoning of the studied skarn indicate fluid-induced reactions at the contact of durbachite with marble. The process seems to have taken place in several stages.

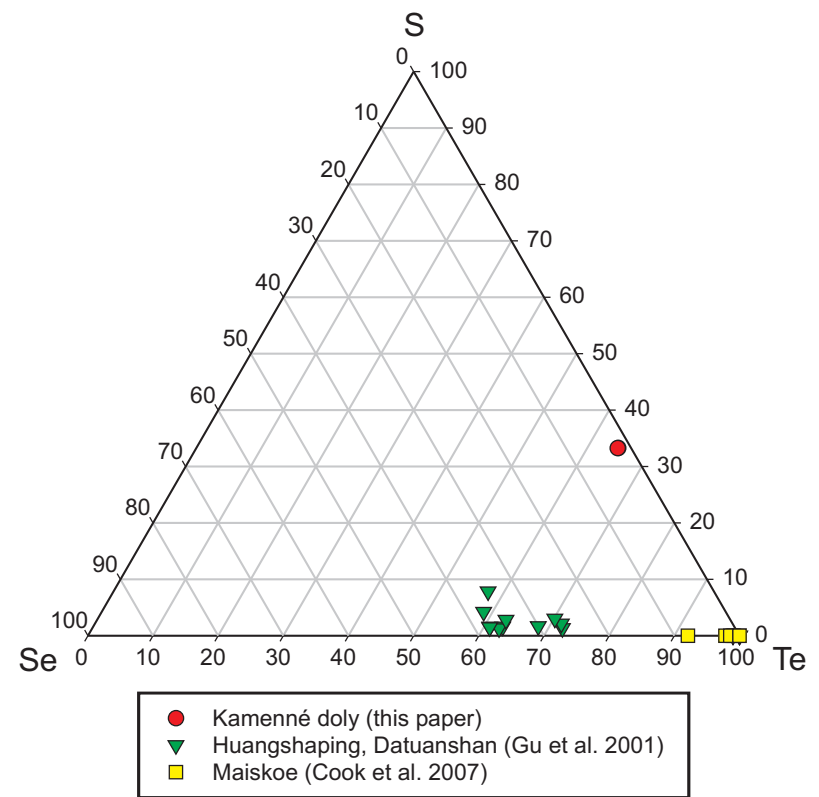

Fig. 12 Ternary plot $\mathrm{Se}-\mathrm{S}-\mathrm{Te}$ for $\mathrm{Bi}_{2} \mathrm{X}$ mineral from Kamenné doly.

(1) At the first, prograde stage, formed magnesiumrich minerals of the marble and skarn under conditions of a high activity of $\mathrm{Mg}, \mathrm{Al}$ and $\mathrm{F}$ and a rather low activity of $\mathrm{Fe}$ and $\mathrm{S}$. This is indicated by an increased content of Al- and Mg- component in cores of clinopyroxene, by presence of phlogopite in skarn unit II as well as chondrodite, spinel and fluorine-rich phlogopite in marble. The mineral assemblage in marble suggests introduction of $\mathrm{Si}$ and most of $\mathrm{F}$ from an external source, as indicated by the substantial amount of chondrodite (up to 30 vol. \%).

(2) Activity of $\mathrm{Ca}$ and Fe significantly increased during the second prograde stage. In all skarn units, particularly in the Unit III, hedenbergite grew at reducing conditions, as magnetite is absent. Unit II, which builds much of the skarn body, was formed, together with the Unit I characterised by wollastonite, vesuvianite and garnet with somewhat increased content of pyralspite end-members. Development of hedenbergite veins in marble, containing niobian titanite, and possibly accessory $\mathrm{Bi}$ and $\mathrm{Bi}$-Te minerals, most probably took place at this stage as well. Lastly, the bulk of scheelite mineralization was formed (fine-grained scheelite in association with hedenbergite and pyrrhotite).

(3) The main mass of pyrrhotite, pyrite, arsenopyrite and coarse-grained scheelite originated in the third stage of retrograde character. It was associated with a crystallization of Fe-amphibole at reducing conditions and high activity of $\mathrm{Fe}$ and $\mathrm{S}$ and with an intense brittle deformation of skarn in final stage. 
(4) The fourth, low-temperature post-skarn stage coincided with fracture filling by siderite and/or quartz veins.

Such a development corresponds to published models of multistage skarn evolution, from an early high-temperature stage of Mg-skarn, through the main stage of Ca-skarn to post-skarnization processes (e.g. Zharikov 1970; Shabynin 1973; Einaudi et al. 1981, Aleksandrov 1998; Meinert 1992).

\section{Conclusions}

Skarn at Kamenné doly near Písek containing accessory niobian titanite, Bi-(sulpho) tellurides, scheelite with $\mathrm{Fe}-$ and $\mathrm{Fe}-\mathrm{As}$ sulphides is associated with the contact of chondrodite marble with melanocratic granite to quartz syenite (durbachite). Massive sulphide-scheelite-rich calcic skarn consists of several units (Units I-V), which were formed during several stages of reactions between marble and infiltrating $\mathrm{Fe}$, Si-rich fluids derived from adjacent plutonic rocks (durbachite). Several stages of brittle deformation, which took place during skarn evolution, enhanced the migration of fluids significantly.

Pyrrhotite, pyrite and arsenopyrite locally accumulate in the predominant clinopyroxene and amphibole skarn. Scheelite mineralization corresponds to the type of reduced skarn with hedenbergite, andradite-grossular, pyrrhotite and Mo-free scheelite (Einaudi et al. 1981; Meinert 1992). Among accessory opaque minerals is worth noting the presence of native $\mathrm{Bi}$ and Bi-tellurides of the $\mathrm{Bi}_{2} \mathrm{X}$ a $\mathrm{Bi}_{5} \mathrm{X}_{3}$ series.

Hedenbergite vein in marble can be considered as an independent skarn type, characterised by the presence of accessory niobian titanite. Niobian titanite contains elevated contents of $\mathrm{Nb}$ (up to $0.164 a p f u$ ) as well as $\mathrm{Ta}$ $(\leq 0.038$ apfu $), \mathrm{Al}, \mathrm{Fe}, \mathrm{Sn}, \mathrm{Zr}$ and F. The Kamenné doly locality is one of few so far published occurrences of niobian titanite in calc-silicate rocks worldwide. Possibly, niobian titanite may be a not-so-rare accessory in calcsilicate rocks, mainly those of the W- and Sn-subtype of skarns. Thus, determination of $\mathrm{Nb}$ in titanite from these mineral assemblages is strongly recommended.

Acknowledgments. Authors thank to prof. Z. Pertold, prof. M. Novák and dr. V. Janoušek for critical comments on the manuscript. The work was funded by the research projects MK00002327201 (to JS and JL) and MK00009486201 (SH and JC) of the Ministry of Culture of the Czech Republic.

\section{References}

Aleksandrov SM (1998) Geochemistry of Skarn and ore Formation in Dolomites. VSP, Utrecht, Netherlands, pp 1-300 (in Russian)

Anthony JW, Bideaux RA, Bladh KW, Nichols MC (1990) Handbook of Mineralogy: Volume I, Elements, Sulfides, Sulfosalts. Mineral Data Publishing, Tucson, Arizona, pp 1-588

Bernau R, Franz G (1987) Crystal chemistry and genesis of Nb-, V-, and Al-rich metamorphic titanite from Egypt and Greece. Canad Mineral 25: 695-705

Brigatti MF, Caprilli E, Mottana A, Poppi L (2004) Nbcontaining titanite: new data and crystal structure refinement. Neu Jb Mineral, Mh 3: 117-126

Chakhmouradian AR (2004) Crystal chemistry and paragenesis of compositionally-unique (Al-, Fe-, Nb-, and Zr-rich) titanite from Afrikanda, Russia. Amer Miner 89: $1752-1762$

Cícha J (2003) Minerals of the Kamenné doly quarry near Písek. Minerál 11: 86-89 (in Czech)

Č́nnÝ P, Novák M, Chapman R (1995) The Al(Nb, Ta)Ti substitution in titanite. The emergence of a new species. Mineral Petrol 52: 61-73

Cook JN, Ciobanu CL, Wagner T, Stanley ChJ (2007) Minerals of the system $\mathrm{Bi}-\mathrm{Te}-\mathrm{Se}-\mathrm{S}$ related to the tetradymite archeotype: review of classification and compositional variation. Canad Mineral 45: 665-708

Dallmeyer RD, Franke W, Weber K. (eds) (1995) PrePermian Geology of Central and Eastern Europe. Springer-Verlag, Berlin, pp 1-593.

Dimitrova D, Kerestedjian T (2006) Bismuth minerals in the postskarn sulphide-arsenide mineralization in the Martinovo iron deposit, NW Bulgaria. Geochem Mineral Petrol (Sofia) 44: 19-32

DrÁbeK M, FrÝDA J, JANOUŠEK V (1999) Regionally metamorphosed carbonatite-like marbles from the Varied Group, Moldanubian Unit, Bohemian Massif, Czech Republic, and their Mo-Th-Nb-REE mineralization. In: Stanley CJ et al. (eds) Mineral Deposits: Processes to Processing, Proceed. $5^{\text {th }}$ SGA meeting and $10^{\text {th }}$ IAGOD meeting 1999, Balkema, Rotterdam, pp 635-638

Drahota P, Pertold Z, Pudilová M (2005) Three types of skarn in the northern part of the Moldanubian Zone, Bohemian Massif - implications for their origin. J Czech Geol Soc 50: 19-33

Einaudi MT, Meinert LD, Newberry RJ (1981) Skarn deposits. Econ Geol 75: 317-391

Fišera M, Bernard JH, Horáková V, Malecha A, Manová M, Odehnal L, Š́alansKÝ K (1978) Explanations to the geological map of ČSSR 1:25 000 sheet 22-412 Kluky. Czech Geological Survey Prague, pp 7-58 (in Czech)

Fišera M, RybKa R, Moravcová H (1986) Contact skarn containing scheelite from Semice near Písek (South 
Bohemia, Czechoslovakia). Čas Nár muz, ř př́rod 155: 72-80 (in Czech)

GASPAR JC (1992) Titanian clinohumite in the carbonatites of the Jacupiranga Complex, Brazil: mineral chemistry and comparison with titanium clinohumite from other environments. Amer Miner 77: 168-178

Groat LA, Hawthorne FC, Ercit S (1992) The chemistry of vesuvianite. Canad Mineral 30: 19-48

Gu XP, Watanabe M, Hoshino K, Shibata Y. (2001) Mineral chemistry and associations of $\mathrm{Bi}-\mathrm{Te}(\mathrm{S}, \mathrm{Se})$ minerals from China. Neu Jb Mineral, Mh 289-309

Harlov D, Tropper P, Seifert W, Nijland T, Förster HJ (2006) Formation of Al-rich titanite $\left(\mathrm{CaTiSiO}_{4} \mathrm{O}-\mathrm{CaAl}-\right.$ $\mathrm{SiO}_{4} \mathrm{OH}$ ) reaction rims on ilmenite in metamorphic rocks as a function of $f \mathrm{H}_{2} \mathrm{O}$ and $f \mathrm{O}_{2}$. Lithos 88: 72-82

HouzAR S (1998) Skarns in Moravian part of Moldanubicum, a review. Bull mineral-petrolog Odd Nár Muz (Praha) 6: 77-83 (in Czech).

HouZAR S (2004) Metamorphosed carbonate rocks at the south-eastern margin of the Bohemian Massif. Unpublished PhD Thesis, Faculty of Science, Masaryk University Brno, pp 1-154 (in Czech)

Houzar S, Novák M (2002) Marbles with carbonatite-like geochemical signature from variegated units of the Bohemian Massif, Czech Republic, and their geological significance. J Czech Geol Soc 47: 103-109

HouZAR S, NovÁK M (2006) Clintonite-bearing assemblage in chondrodite marbles from the Moldanubian Zone, western Moravia, Bohemian Massif. J Czech Geol Soc 51: 249-258

Houzar S, Novák M, Doležalová H, Hrazdil V, PfeifEROVÁ A (2006) Mineralogy, petrography and geology of the Nedvědice marbles, Svratka Crystalline Complex; a review. Acta Mus Moraviae, Sci Geol 91: 3-77 (in Czech)

KratochVíl J (1962) Topographic Mineralogy of Bohemia V (O- ̌ $)$. ČSAV, Prague pp 1-491 (in Czech)

KRETZ R (1983) Symbols for rock-forming minerals. Amer Miner 68: 277-279

Liferovich RP, Mitchell RH (2005) Composition and paragenesis of $\mathrm{Na}-, \mathrm{Nb}$ - and $\mathrm{Zr}$-bearing titanite from Khibina, Russia and crystal-structure data for synthetic analogues. Canad Mineral 43: 795-812

Liferovich RP, Mitchell RH (2006) Solid solutions of niobium in synthetic titanite. Canad Mineral 44: 1089-1097

LitochleB J, ŠReIN V (1994) Bismuth and tellurium minerals from gold-bearing deposits and occurrences in the Czech Republic. Bull mineral-petrolog Odd Nár Muz (Praha) 2: 89-105 (in Czech)

MeINERT LD (1992) Skarns and Skarn Deposits. Geoscience Canada 19: 145-162

MorÁveK P (1992) Deposits and occurrences of gold in Moldanubian Zone. In MorÁvek P (ed) Gold in the
Bohemian Massif. Czech Geological Survey Prague, pp 105-120

NĚMEC D (1991) Regional typization of the iron skarns of the Bohemian-Moravian Heights (Českomoravská vrchovina). Acta Mus Moraviae, Sci Nat 76: 51-82

Newberry RJ (1998) W- and Sn-skarn deposits: a 1998 Status Report. In LENTZ DR (ed) Mineralized intrusionrelated skarn systems. MAC Short Course Volume 26: 289-335

NovÁk M, Šrein V, HouZAR S (1990) Chemical composition of titanite from various calc-silicate rocks and associated pegmatites in the eastern part of the Moldanubicum, western Moravia. Acta Mus Moraviae, Sci Nat 75: 3-20

Paul BJ, Černý P, Chapman R, Hinthorne RJ (1981) Niobian titanite from the Huron Claim pegmatite, southeastern Manitoba. Canad Mineral 19: 549-552

Pertold Z, Pertoldová J Pudilová M (1997) Metamorphic history of skarns in the Gföhl unit, Moldanubicum, Bohemian Massif, and implications for their origin. Acta Univ Carol, Geol 41: 157-166

Pouchou JL, Pichoir F (1985) "PAP" procedure for improved quantitative microanalysis. Microbeam Analysis 20: $104-105$

SAто K (1982) Characteristics of Tungsten Skarns in Japan, Two Contrasting Types. In: Hepworth JV, Yu HZ (eds) Proc Symp Tungsten Geology, Jiangxi 1981 ESCAP/ RMRDC and Geological Publishing House Beijing, pp 203-209

Sengupta P, Raith MM, Datta A (2004) Stability of fluorite and titanite in a calc-silicate rock from the Vizianagaram area, Eastern Ghats Belt, India. J Metamorph Geol 22: 345-359

Shabynin LI (1973) Formation of magnesian skarns. Nauka, Moscow, pp 1-173 (in Russian)

ShimaZAKi H (1977) Grossular-spessartine-almandine garnets from some Japanese scheelite skarns. Canad Mineral 15: 74-80

SuK M (1974) Lithology of Moldanubian metamorphics. Čas Mineral Geol 19: 373-389

ŠArbach M, DrábeK M, Veselovský F (1985) Mo-Th-Nblanthanide mineralization of marbles in Václav Mine at Bližná. Geol Průzk 16: 9-10 (in Czech)

SzelEg E (2003) The crystal chemistry of tin in titanite. Mineral Soc of Poland Special papers 22: 218-220

Zharikov VA (1970) Skarns, part I, II and III. Int Geol Rev 12: pp 541-559, 619-647 and 760-775. 


\section{Neobvyklá mineralizace s niobovým titanitem a Bi-telluridy v scheelitovém skarnu v lomu Kamenné doly u Písku, moldanubikum, Český masiv}

Neobvyklá minerální asociace s niobovým titanitem, ryzím Bi a Bi-(sulfo)telluridy byla zjištěna v scheelitovém skarnu na kontaktu chondroditového mramoru a melanokratního granitu (durbachitu). Objemově převládá na styku mramoru a durbachitu masivní skarn. Ve skarnu lze vyčlenit 5 jednotek s odlišnou minerální asociací: (I) Di + Grs \pm Wo \pm Ves \pm Qtz; (II) Di + Qtz \pm Phl; (III) Cpx ( \pm žilky Grt, Qtz); (IV) Cpx-Amp, zrudněný sulfidy a scheelitem; (V) Po-Py-Apy + Sch + Ap, které převládají nad Cpx + Amp.

$\mathrm{Na}$ lokalitě je niobový titanit $\mathrm{v}$ akcesorickém množství zastoupen zejména $\mathrm{v}$ tenkých žilách hedenbergitového skarnu pronikajícího mramorem. Vedle vyššího obsahu $\mathrm{Nb}(\leq 0,164$ apfu $\mathrm{Nb})$ a lokálně i Ta $\left(\leq 0,038\right.$ apfu Ta $\left.{ }^{5+}\right)$, je rovněž relativně bohatý $\mathrm{Al}$ a lokálně obsahuje mírně vyšší koncentrace Fe, Sn, Zr a F. Vzácný je v asociaci s vesuvianem a grossularem v masivním skarnu (jednotka I), kde má relativně nízký obsah $\mathrm{Nb}(\leq 0,028$ apfu $)$ a zejména $\mathrm{Ta}(\leq 0,002$ apfu $)$; i tyto obsahy jsou však zřetelně vyšší než u titanitu z běžných vápenatosilikátových hornin. Zřetelná negativní korelace $\mathrm{Nb}^{5+} \mathrm{vs} \mathrm{Ti}^{4+} \mathrm{a} \mathrm{Al}^{3+} \mathrm{vs} \mathrm{Ti}^{4+}$ odpovídá převažujícím substitucím $\mathrm{Al}(\mathrm{OH}, \mathrm{F})(\mathrm{TiO})$-1 a hlavně $\mathrm{AlNbTi}_{-2}$. Niobový titanit (obsah $\mathrm{Nb}>0,03 \mathrm{apfu}$ ) představuje ve skarnech dosud výjimečnou minerální fázi, popsanou pouze z jedné lokality na světě. Ryzí Bi je jednak vzácnou akcesorií v mramoru, jednak relativně častým akcesorickým minerálem masivního skarnu, zrudněného scheelitem, pyritem, pyrhotinem a arzenopyritem. Vzácně je doprovázen dosud nepojmenovanými Bi-(sulfo)telluridy sérií $\mathrm{Bi}_{2} \mathrm{X}$ a $\mathrm{Bi}_{5} \mathrm{X}_{3}$, které velmi vzácně vystupují v trhlinách arsenopyritových zrn.

Skarn vznikl pravděpodobně reakcí fluid s mramory, přičemž lze rozlišit starší Mg-etapu a mladší Ca-etapu bohatší Fe. Z hlediska zrudnění byla důležitá retrográdní etapa, při níž krystalizovala hlavní část scheelitu a sulfidů, v závěrečné etapě vznikly křemen-sideritové žíly. 